Portland State University

PDXScholar

\title{
How Does Transportation Affordability Vary Among TODs, TADs, and Other Areas?
}

\author{
Brenda Scheer \\ University of Utah \\ Reid Ewing \\ University of Utah \\ Keunhyun Park \\ University of Utah \\ Shabnam Sifat Ara Khan \\ University of Utah
}

Follow this and additional works at: https://pdxscholar.library.pdx.edu/trec_reports

Part of the Transportation Commons, Urban Studies Commons, and the Urban Studies and Planning Commons

Let us know how access to this document benefits you.

\section{Recommended Citation}

Scheer, B.C., Ewing, R., Park, K., \& Khan, S.S. How does transportation affordability vary among TODs, TADs, and other areas? NITC-RR-859. Portland, OR: Transportation Research and Education Center (TREC), 2017. https://doi.org/10.15760/trec.181

This Report is brought to you for free and open access. It has been accepted for inclusion in TREC Final Reports by an authorized administrator of PDXScholar. Please contact us if we can make this document more accessible: pdxscholar@pdx.edu. 

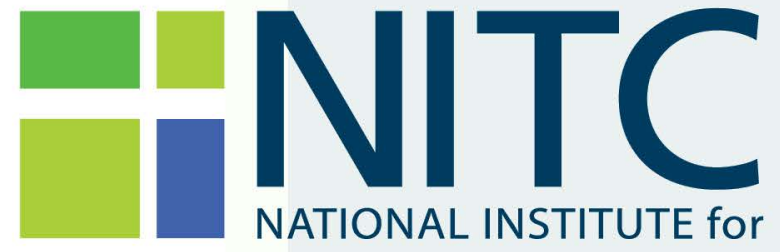

TRANSPORTATION and COMMUNITIES

FINAL REPORT

How does transportation affordability vary among TODs, TADs, and other areas?

NITC-RR-859 August 2017

NITC is a U.S. Department of Transportation national university transportation center.

=H: TREC 



\title{
HOW DOES TRANSPORTATION AFFORDABILITY VARY AMONG TODS, TADS, AND OTHER AREAS? Final Report
}

\section{NITC-RR-859}

\author{
by \\ Brenda Scheer (PI) \\ Reid Ewing \\ Keunhyun Park \\ Shabnam Sifat Ara Khan \\ University of Utah
}

for

National Institute for Transportation and Communities (NITC)

P.O. Box 751

Portland, OR 97207
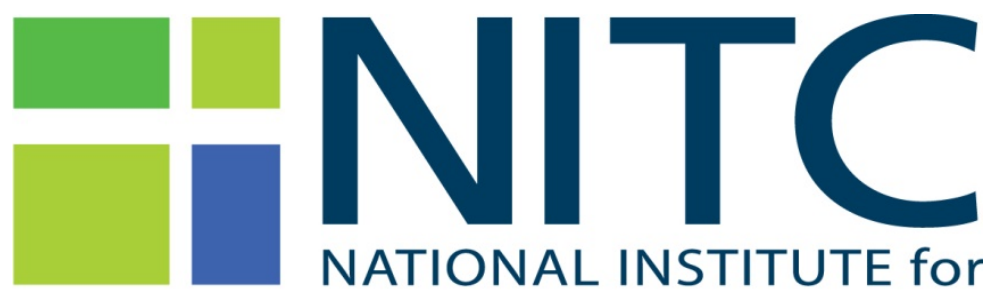

TRANSPORTATION and COMMUNITIES

August 2017 




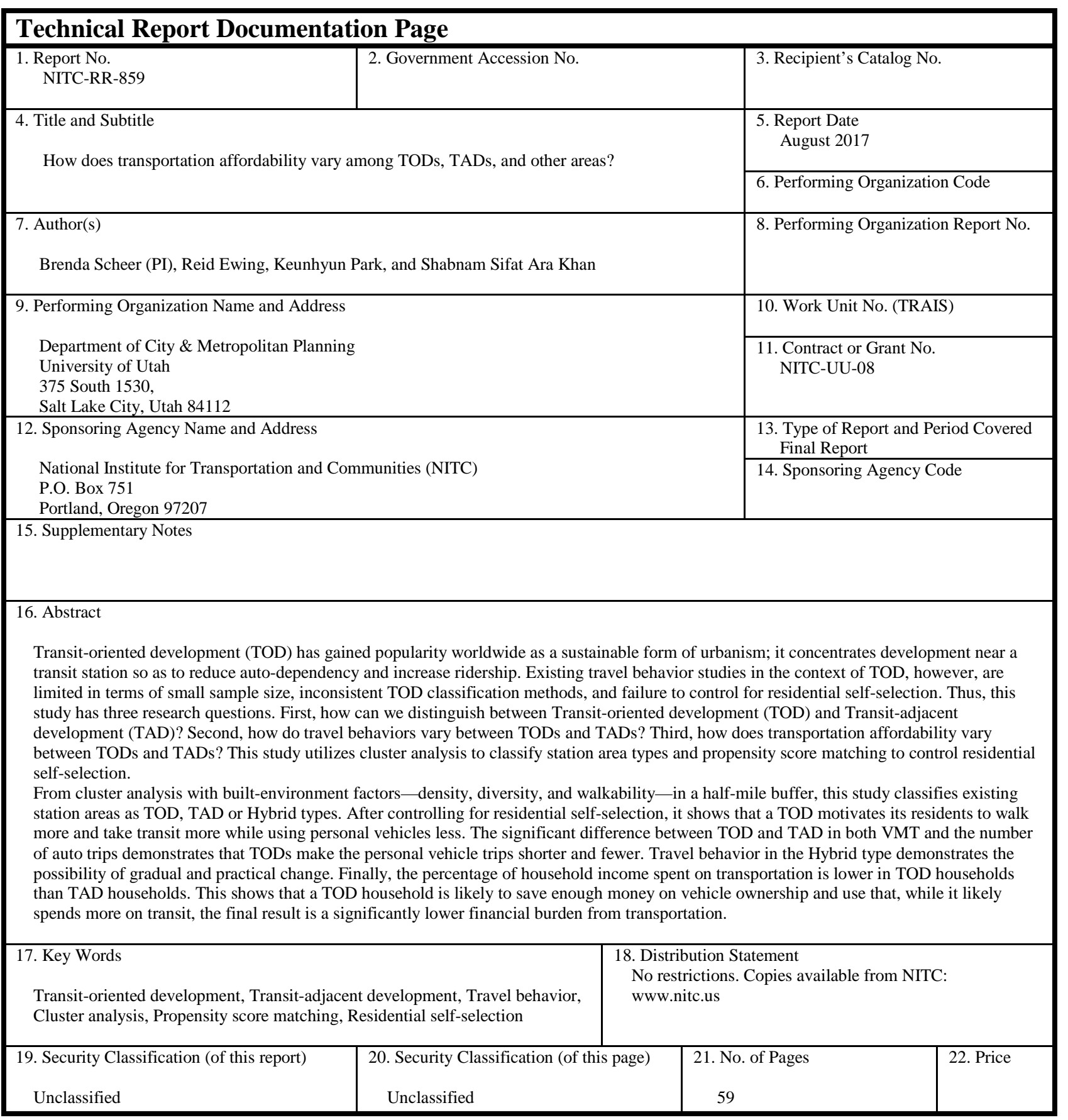





\section{ACKNOWLEDGEMENTS}

This project was funded by the National Institute for Transportation and Communities (NITC) under grant number 859.Furthermore, we acknowledge and thank the anonymous peer reviewer who provided immensely helpful insights and corrections to this report.

\section{DISCLAIMER}

The contents of this report reflect the views of the authors, who are solely responsible for the facts and the accuracy of the material and information presented herein. This document is disseminated under the sponsorship of the U.S. Department of Transportation University Transportation Centers Program in the interest of information exchange. The U.S. Government assumes no liability for the contents or use thereof. The contents do not necessarily reflect the

official views of the U.S. Government. This report does not constitute a standard, specification, or regulation.

\section{RECOMMENDED CITATION}

Scheer, B.C., Ewing, R., Park, K., \& Khan, S.S. How does transportation affordability vary among TODs, TADs, and other areas? NITC-RR-859. Portland, OR: Transportation Research and Education Center (TREC), 2017. 



\section{TABLE OF CONTENTS}

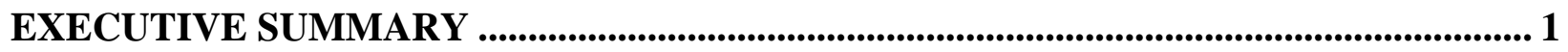

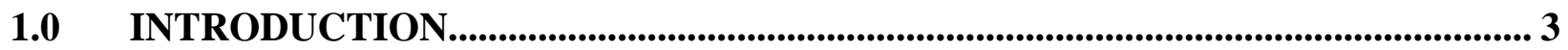

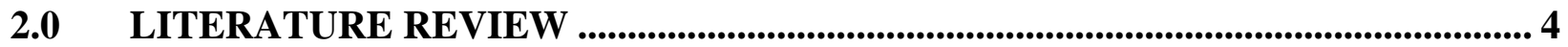

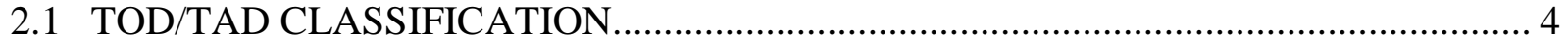

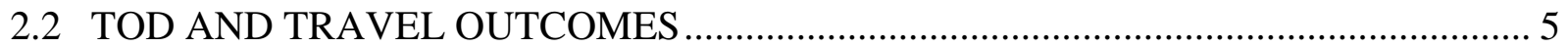

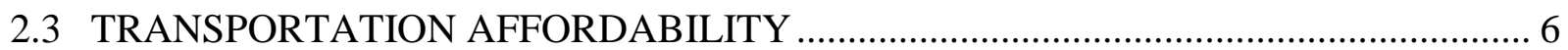

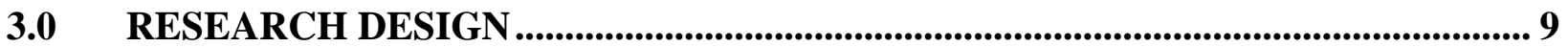

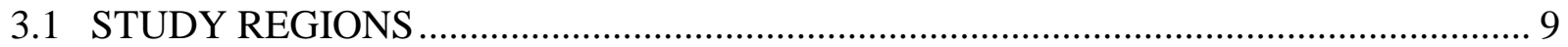

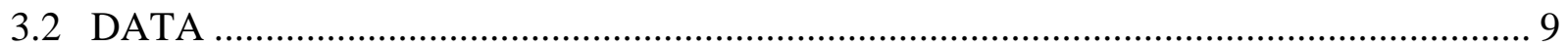

3.3 RESEARCH PROCESS AND METHODS ……………………………………...... 10

3.3.1 Step 1. TOD/TAD classification: Cluster analysis .................................................... 11

3.3.2 Step 2. Household sample selection: Propensity score matching .............................. 11

3.3.3 Step 3. Analysis of transportation affordability ....................................................... 12

4.0 TOD/TAD CLASSIFICATION: CLUSTER ANALYSIS .......................................... 16

5.0 TRAVEL BEHAVIOR IN TOD VS. TAD HOUSEHOLDS: PROPENSITY SCORE

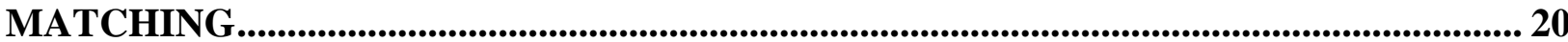

6.0 TRANSPORTATION AFFORDABILITY IN TOD VS. TAD HOUSEHOLDS ..... 23

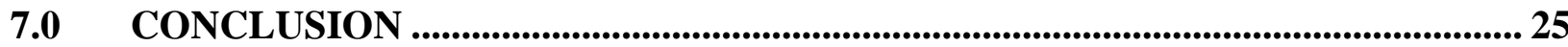

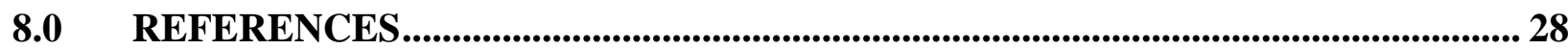

9.0 APPENDICES ....................................................................................................................... 35

9.1 APPENDIX A: LIST OF STATION AREAS BY TYPE ……………………................ 35

\section{LIST OF TABLES}

Table 3-1: Study regions and transit stations ${ }^{1}$

Table 3-2. Top 10 automobiles and average ownership cost for lowest and highest income bracket in eight regions from NHTS and Edmunds Inc. data.

Table 3-3. Average gasoline price per gallon (2010) for eight regions .................................. 14

Table 3-4. Average transit fare (2010) for eight regions .......................................................... 14

Table 4-1. Cluster analysis result and descriptive statistics................................................... 16

Table 4-2. Household characteristics and travel behavior by station area types: average and ANOVA analysis........................................................................................... 18

Table 5-1. Mean differences of observed covariates between TOD and TAD in unmatched and matched samples ................................................................................................ 20

Table 5-2. Differences in travel behavior between station area types after matching ......... 22

Table 6-1. Differences in transportation cost and affordability before matching $(n=2,455) 23$

Table 6-2. Differences in transportation cost and affordability after matching: TOD-TAD pairs $(\mathbf{n}=108)$. 
Table 6-3. Differences in transportation cost and affordability after matching: TOD-

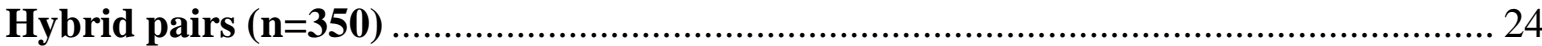

Table 6-4. Differences in transportation cost and affordability after matching: TAD-

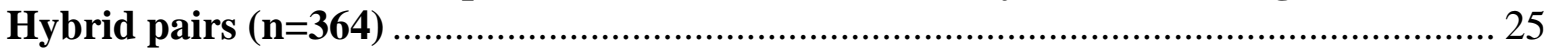

\section{LIST OF FIGURES}

Figure 2-1. Built-Environment Factors of a TOD .................................................................... 4

Figure 3-1. Research process of this study …………….......................................................... 10

Figure 3-2. The relationship between observed effect and treatment effect (Cao, Xu and Fan, 2010) 12

Figure 4-1. Examples of each station area type (Image Source: Google Maps).......................... 17

Figure 4-2. Mode Share by Station Area Type ( $\mathrm{n}$ is total number of trips in each area type)...... 19 


\section{EXECUTIVE SUMMARY}

Transportation has increased from the sixth-largest expenditure (less than 2\%) in U.S. household budgets in 1917 to the second-largest since the 1970s (17\% in 2014; U.S. Bureau of Labor Statistics, 2014). In recent decades, transit-oriented development (TOD) has gained popularity worldwide as a sustainable form of urbanism; it concentrates developments near a transit station so as to minimize auto-dependency and maximize ridership. This study defines TOD as any dense, mixed-use, and walkable area near a transit station, and transit-adjacent development (TAD) as any low-density, single-use, and car-dependent area near a station. A TOD project should give people more transportation options and thereby decrease their transportation cost.

Existing TOD studies, however, have limits: 1) limited number of study sites, 2) no systematic method to distinguish TOD from other types of station area, and 3) no control for the impact of residential self-selection on travel behavior. This study has three research questions. First, how can we distinguish between TOD and TAD? Second, how do travel behaviors vary between TODs and TADs? Third, how does transportation affordability vary between TODs and TADs?

To answer these questions, we utilize cluster analysis to classify station area types and propensity score matching to control for residential self-selection. For better generalizability, the data are collected from household travel surveys in eight urban areas across the U.S.-Atlanta, Georgia; Boston, Massachusetts; Denver, Colorado; Miami, Florida; Minneapolis-St. Paul, Minnesota; Portland, Oregon; Salt Lake City, Utah; and Seattle, Washington. From the travel survey data in the eight regions, we calculated automobile trips, vehicle miles traveled (VMT), transit trips and walk trips by individual households.

This study consists of three steps. First, following the definition of TOD and the literature review, we classify station areas based on three built-environment characteristics of TODdensity, diversity, and walkability. The cluster analysis separates station areas into three types. The first cluster (107 out of 549 station areas) is titled "TAD” and has the lowest levels of activity density; land use diversity; and walkability, as measured by intersection density. The second and largest one $(\mathrm{n}=382)$ is classified "Hybrid"; it has low activity density and intersection density, but the highest land use entropy index. The final cluster (n=60), “TOD," has the highest activity density and intersection density, and a high level of land use diversity. We observe that households living in TADs have more household members, more workers, and higher incomes than those living in TODs or Hybrids. Regarding travel behavior, TAD households have much higher VMT and more auto trips, and fewer transit and walk trips than those in TODs and Hybrids. Hybrid households are in the middle for most measurements, except for their lowest household incomes and highest level of transit trips on average.

Second, from the household travel surveys, we select households living in each type of station area. As significant differences among the households of a station area type could make it hard to evaluate the true impact of built environment on travel behavior, this study utilizes propensity score matching (PSM) to make samples comparable and, thus, control residential self-selection. By controlling six explanatory variables - household size, the number of workers, household 
income, distance to nearest transit station, regional job accessibility, and the regions, PSM matched household pairs in three area-type couplets (TOD-TAD, TOD-Hybrid, and TADHybrid). Although the differences in travel outcomes become less dramatic after controlling for self-selection, the matched samples still show that TOD motivates its residents to walk more and take transit more while using personal vehicles less. The significant difference between TOD and TAD in both VMT and the number of auto trips means that TOD makes the personal vehicle trips shorter (39\% shorter VMT per household) and fewer (35\% fewer auto trips per household).

Finally, this study compares travel outcomes among different station area types, and computes household transportation cost using actual travel survey data. Transportation affordability is compared pairwise between TOD, TAD, and hybrid types. Only TAD-TOD pairs show a marginally significant difference in the percentage of household income spent on transportation. This result shows that when a household moves from a TAD to a TOD area, or an existing TADtype station area becomes TOD, the household is likely to save enough money on vehicle ownership and maintenance costs that, while it spends more on transit, the final result is a significant financial savings on transportation.

This study could have practical implications in station-area planning. The result shows that the numbers of auto trips, transit trips, and walk trips are slightly different between TAD and Hybrid areas, and that the numbers of auto and walk trips are significantly different between TOD and Hybrid. Thus, when a local government or transit authority develops a sprawled, single-use, and unwalkable TAD-type station area into a Hybrid type - by, for instance, adding different land uses - it could expect small increases in transit and walk trips. Then a Hybrid type of station area could be changed into a TOD type through either infill or new developments by adding density and decreasing block sizes, which would result in less driving and more walking by the residents. Then the cumulative change from TAD to TOD could encourage its residents to drive shorter and less, walk more, and take transit more, which would have positive impacts on the city's environment, society, and economy. 


\subsection{INTRODUCTION}

Transportation has increased from the sixth-largest expenditure (less than 2\%) of U.S. household budgets in 1917 to the second-largest since the 1970s (17\% in 2014; U.S. Bureau of Labor Statistics, 2014). In recent decades, transit-oriented development (TOD) has gained popularity worldwide as a sustainable form of urbanism; it concentrates developments near a transit station so as to minimize auto-dependency and maximize ridership. A TOD project should give people more transportation options and thereby decrease their transportation cost.

Much of the literature verifies that TODs enhance the use of public transit and reduce car usage (Cervero, 1993, 2004; Langlois et al., 2015; Nasri and Zhang, 2014; Olaru and Curtis, 2015; Venigalla and Faghri, 2015). Existing TOD studies, however, have limits: 1) limited number of study sites, 2) lack of a systematic method to distinguish TOD from other types of station area, and 3) no control for the impact of residential self-selection on travel behavior. There are many exceptions to the above limitations (for a recent robust study dealing with the first two, see Renne et al., 2016), but no study overcomes all three limitations. As a result, it is hard to generalize the findings from the literature to other regions. Also, researchers and planners might not agree with TOD classification in certain studies, which limits the practical implication for transit officials and planners. Finally, when it fails to control for self-selection, the result might overestimate the impact of TOD urban form on travel behavior.

Thus, this study has three research questions. First, how can we distinguish between a transitoriented development (TOD) and a transit-adjacent development (TAD)? Second, how do travel behaviors vary between TODs and TADs? Third, how does transportation affordability vary between TODs and TADs? To answer these questions, we utilize cluster analysis to classify station area types and propensity score matching to control for residential self-selection. For better generalizability, the data are collected from household travel surveys in eight urban areas across the U.S. with exact XY coordinates for households and trip ends, and household-level measurements of travel activities such as automobile, transit and walk trips. These measures are taken because this study seeks to isolate the impact of living in TOD—or another type of station area-on travel behavior.

There is broad interest in the planning and policy communities for accurate tools that predict the consequences of TOD on the generation of transit ridership and reduction of automobile usage. Our analysis will help guide transportation planners and decision-makers to evaluate or model TOD projects for the promotion of sustainable travel behavior and subsequent economic, social, and environmental impacts. 


\subsection{LITERATURE REVIEW}

\subsection{TOD/TAD CLASSIFICATION}

Bernick and Cervero (1997, p.5) define transit-oriented development (TOD) as "a compact, mixed-use community, centered around a transit station that, by design, invites residents, workers, and shoppers to drive their cars less and ride mass transit more.” Kamruzzaman et al. (2015) state that TOD is a neighborhood that is served by public transit services and offers amenities such as density; walkable, well-connected street patterns; and diversified land uses. Transit-adjacent development (TAD) is often defined by characteristics that show how it fails to be a TOD. A TAD is a noncompact, segregated neighborhood development that calls for auto use instead of inviting walk trips (Belzer and Autler, 2002; Cervero and Duncan, 2002; Dittmar and Ohland, 2004). Halbur (2007) specifies that its lack of a connected street pattern and diverse land use makes a TAD an "evil twin" of a TOD. This study defines TOD as any dense, mixeduse, and walkable area around a transit station, and TAD as any low-density, single-use, and cardependent station area.

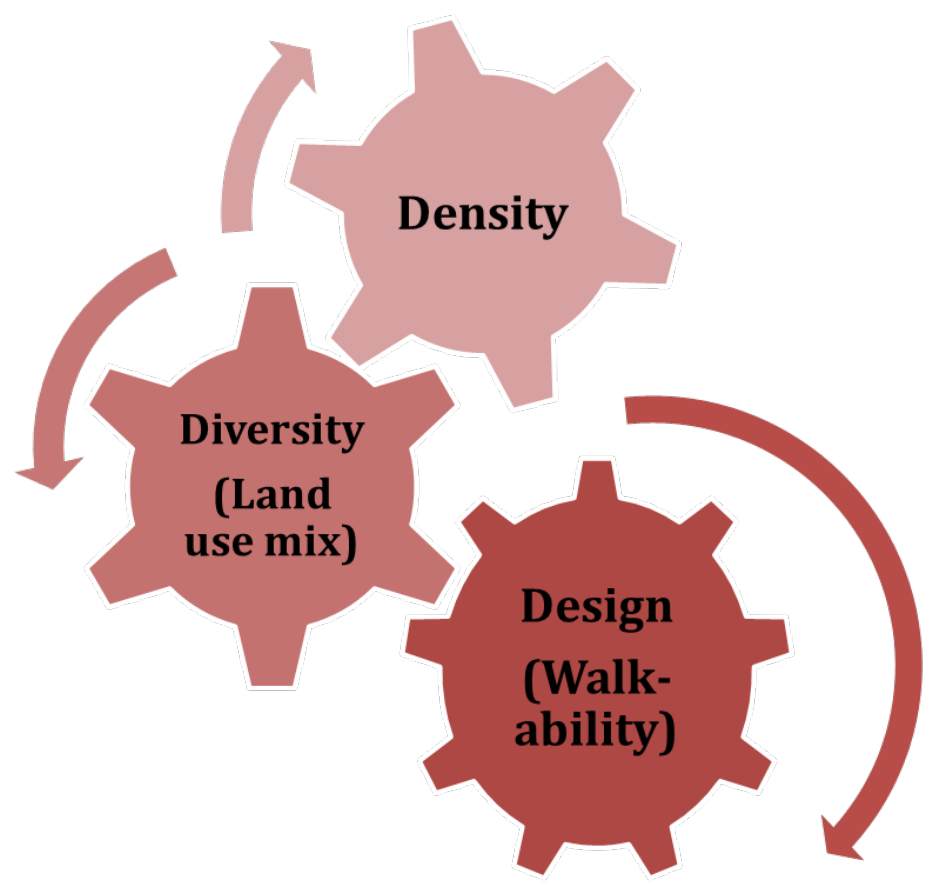

Figure 2-1. Built-Environment Factors of a TOD

The most frequently studied factors for classifying a TOD from other types of station area are residential and employment density (Renne and Ewing, 2013; Kamruzzaman et al., 2015; Laaly, 2014; Pollack et al., 2014; Jeihani et al., 2013; Canepa, 2007; Cervero and Kockelman, 1997; Cervero and Gorham, 1995), land use diversity (Renne and Ewing, 2013; Kamruzzaman et al., 2015; Vale, 2015; Jeihani et al., 2013; Cervero and Kockelman, 1997; Cervero and Gorham, 
1995), and walkability or street connectivity (Renne and Ewing, 2013; Vale, 2015; Pollack et al., 2014; Laaly, 2014; Ngo, 2012; Kamruzzaman et al., 2014; Brown and Werner, 2011; Werner, Brown and Gallimore, 2010). Recent studies trying to classify TOD and TAD deal with all three factors in the analysis (Renne and Ewing, 2013; Kamruzzaman et al., 2015; Jeihani et al., 2013).

There are several ways to distinguish TOD from TAD, such as cluster analysis (Kamruzzaman et al., 2015; Vale, 2015) or scoring (Jeihani et al., 2013; Laaly, 2014; Pollack et al., 2014; Renne and Ewing, 2013). As classifying factors, Kamruzzaman et al. (2015) include residential and employment density, public transport accessibility levels (PTALs), land use diversity, and street connectivity levels as measured through intersection density and cul-de-sac density. They then identify five types of station neighborhoods - urban TODs, activity center TODs, potential TODs, TADs, and traditional suburbs. Vale (2015) uses six place-index measurementsresidential density, employment density by four sectors, and degree of functional mix - and seven node-index measurements, and then identifies six types of station area-urban TODs, balanced TADs, suburban TODs, undersupplied transit TODs, unbalanced TODs, and future TODs. Using a scoring method, Pollack et al. (2014) divide station areas into four groupsTransit-Oriented, Transit-Supportive, Transit-Related, and Transit-Adjacent.

Existing studies distinguishing TOD from TAD to compare their performance are limited. First, most studies cover only one or a few regions. Although Renne and Ewing (2013) studied 54 regions across the U.S., the outcome variable is not comprehensive travel behavior, but only the percentage of people who commute via public transportation. In contrast, this study includes eight urban areas in various geographic, socioeconomic conditions in the U.S. to examine various travel behaviors using household travel survey data. Second, unlike existing studies relying on straight-line catchment areas (Vale, 2015) or simple scoring systems (Renne and Ewing, 2013), this study utilizes network distance from each station, and cluster analysis. Finally, while Kamruzzaman et al. (2015) establish a robust method of classification, their study analyzes all neighborhoods in a city, Brisbane, Australia. Instead, we use the station-based approach as a focus of TOD and TAD because we deal with the built environments of station areas and their impact on travel behavior, which has more direct implications for planning practice.

\subsection{TOD AND TRAVEL OUTCOMES}

The benefits of TOD include promoting active modes of transportation, improving access to opportunities such as job or entertainment, offering alternative mobility options and affordable housing for low-income people, reducing greenhouse gas emissions, and stimulating public and private investments in development and community benefits (Center for Transit-Oriented Development, 2011; Noland et al., 2014). Thus, TOD serves interrelated goals for making communities socially, economically and environmentally more robust and sustainable.

To achieve these goals, a TOD should first create settings that prompt people to drive less and ride public transit more (Cervero, 2004). Among various indicators of performance in a TOD, transportation professionals saw transit ridership as the most important, followed by density, parking indicators, design quality indicators and tax revenue (Renne, 2005). In a book published by the Center for Transit Oriented Development (2010), the authors identified vehicle miles 
travelled (VMT) as the key performance measure for TOD, expressing their understanding that lower VMT results when people walk, bike, and use transit more, and have more transportation options.

Much of the literature verifies that TODs enhance the use of public transit and reduce car usage (Cervero, 1993, 2004; Langlois et al., 2015; Nasri and Zhang, 2014; Olaru and Curtis, 2015; Venigalla and Faghri, 2015). Based on data from 17 TOD projects, Cervero and Arrington (2008) show that residents living in TOD areas are two to five times more likely to commute by transit than their non-TOD counterparts. Nasri and Zhang (2014) find that people living in TOD areas tend to drive less, reducing their VMT by around 21-38\%, compared to the residents of the non-TOD areas even with similar land use pattern in the Baltimore and Washington, D.C., regions. Hale (2014) describes that the mode share by active transportations including transit, walk, and bike accounts for about 50-80\% in TOD areas, which is much higher than the $25-40 \%$ found in TAD areas. Living in TOD promotes more walking and biking as well. Olaru and Curtis (2015) confirm that better biking and pedestrian infrastructure resulted in more bike and walk trips along with higher transit ridership compared to auto-trips in the TOD precincts.

Cervero (2004) found evidence that many TOD ridership gains were a result of self-selectionindividuals who wish to drive less may select homes in transit-oriented environments. Many studies have found associations between attitudes and travel choices as evidence of residential self-selection (Cao, Mokhtarian and Handy, 2009; Mokhtarian and Cao, 2008; Handy, 2004). Thus, individuals' attitudes may confound the relationship between the TOD-type urban form and travel choices, and in turn the effect of the built environment on travel may be overestimated (Ewing, Hamidi and Grace, 2016).

From the review of 38 empirical studies, Cao, Mokhtarian and Handy (2009) seek to control for self-selection bias and examine nine methodological solutions: direct questioning, statistical control, instrumental variables, sample selection, propensity score, joint discrete choice models, structural equations models, mutually dependent discrete choice models, and longitudinal designs. While the authors suggest using longitudinal structural equations modelling with control groups, a propensity score matching (PSM) method is also highly recommended in a nonrandomized observational study, in which it could mimic a randomized experiment using a propensity score (Cao, Mokhtarian and Handy, 2009). The propensity score approach has recently been applied in travel behavior research (Boer et al., 2007; Cao, 2010; Cao, Xu and Fan, 2010; Cao and Fan, 2012; Cao and Schoner, 2014), but not yet in the context of station areas. Detailed explanation of the PSM will be presented in the Research Design section.

\subsection{TRANSPORTATION AFFORDABILITY}

Transportation is the second-biggest expense, after housing, for the majority of American families (Lipman, 2006). However, transportation cost has not garnered as much attention as housing affordability in policy interventions and research until very recently (Agrawal et al., 2011, Rice, 2004). For many years, commuting expenditures were not even included in the transportation calculation (Mattingly and Morrissey, 2014). This made it easier to justify the expansion and creation of more urban sprawl - overlooking the influence of housing location in total household expenditures highlights the lower prices of housing on the urban fringe and 
fosters sprawl development (Dawkins, 2009; Quigley and Raphael, 2005; Glaeser and Gyourko, 2003; Burchell et al., 2000). Further, it does not take into consideration the costs of automobile dependency, vehicle maintenance and fuel for commuting to distant suburbs (Newman and Kenworthy, 1989; Anderson, Kanaroglou and Miller, 1996; Horner, 2002; Low et al., 2005). The tension between the negative environmental impacts and the housing affordability that come with urban sprawl would be better balanced by carefully including in calculations the transportation costs associated with different housing locations (Kellett, Morrissey and Karuppannan, 2012).

To understand the comprehensive cost of commuting, one must focus on transportation affordability. Here, the purpose is to identify the financial burden of the combined housing and transportation expenditures incurred by travelers. Although different affordability measures have been identified, they remain inadequate to grasp the pattern of the commuting cost and the comprehensive concept of transportation affordability (Hamidi, Ewing and Renne, 2016; Mattingly and Morrissey, 2014). Therefore, inconvenient economic realities of suburban life were almost overlooked. The pre-recession swing of financial downturns that increased fuel costs and foreclosures also consumed the lion's share of income for those living in the urban fringe (Hamidi, Ewing and Renne, 2016). Thus, Lipman (2006) showed that $29 \%$ of household incomes were spent on transportation as opposed to $28 \%$ on housing in 28 metropolitan suburbs in a 2006 study. Transportation costs, it should be understood when crafting equitable transportation policies to create affordable mobility for all types of households, are more burdensome for the poor (Agrawal et al., 2011, Jewkes and Delgadillo, 2010, Rice, 2004).

In traditional studies, transportation affordability is measured with respect to household income in order to reflect the financial ability of the different income groups (Haas et al., 2008; Hickey et al., 2012; Sanchez and Brenman, 2007). Then the transportation cost is measured from three components of travel behavior - auto ownership, auto use, and transit use-with each of these modeled outputs weighted by a cost per unit (Haas et al., 2008; Hickey et al., 2012). Haas et al. (2008) estimate that average annual transportation cost over household income is $20.1 \%$ for median-income households in the U.S. From the 25 largest metro areas, Hickey et al. (2012) found that share of income spent on transportation for moderate-income households is from $21 \%$ to $35 \%$ in different regions. Haas et al. (2013) further find that variation in household transportation cost is related more strongly to the characteristics of a neighborhood than the household. On the other hand, Fan and Huang (2011) criticize the traditional measures that focus on the proportion of household income consumed by transportation-related expenditures because these often fail to consider the wide variation in households' transportation needs and locational settings.

On the relationship between housing location and transportation costs, the literature shows that households in areas with high accessibility to job locations save significantly on transportation (Bajic, 1983; Gibbons and Machin, 2005; and So, Tse and Ganesan, 1997). An Australian study (Dodson and Sipe, 2008) about commuting expenditures with respect to housing location shows that as oil prices rise, suburbanites encounter higher financial risk since they depend on private vehicles for everyday commutes. Corroborating such findings, Viggers and Howden-Chapman (2011) report that living in relatively inaccessible suburban locations can pose risk to homeowners' financial sustainability. They specifically identify the lack of public transit and the longer commuting distances as factors causing such financial instability. Currie and Senbergs 
(2007) report similar findings and also that households owned more vehicles in low-density suburbs than in the high-density central parts of a city. They also find lack of accessibility and viable public transit ultimately added to the financial challenges of the residents. In comparison, Hamidi, Ewing and Renne (2016) show that as urban areas become more compact and dense, transportation costs decrease, lowering overall household expenditures. 


\subsection{RESEARCH DESIGN}

\subsection{STUDY REGIONS}

This study includes eight urban areas meeting two criteria. First, we have a household travel survey data with XY coordinates for households and trip ends. Second, the region had a railbased transit system of some sort before its survey was conducted. In the eight regions (Table 31), the household travel surveys were conducted between 2006 and 2012, and we found 549 railbased transit stations from the national TOD Database (Center for Transit Oriented Development, http://toddata.cnt.org). Transit types include heavy rail (109 stations), commuter rail (148 stations), and light rail (272 stations). Boston had the most stations $(n=239)$, followed by Portland ( $n=94)$ and Miami $(n=50)$, and Minneapolis-St. Paul had the fewest $(n=20)$.

Table 3-1: Study regions and transit stations ${ }^{1}$

\begin{tabular}{l|l|l|l|l|l|l|l}
\hline No & Region & $\begin{array}{l}\text { Year } \\
\text { (survey) }\end{array}$ & $\begin{array}{l}\text { Heavy } \\
\text { rail }\end{array}$ & $\begin{array}{l}\text { Commuter } \\
\text { rail }\end{array}$ & $\begin{array}{l}\text { Light } \\
\text { rail }\end{array}$ & Total & $\begin{array}{l}\text { Sample } \\
\text { household } \\
\text { s } \\
(1 / 2 \text { mile })\end{array}$ \\
\hline 1 & Atlanta, GA & 2011 & 38 & 0 & 0 & 38 & 138 \\
\hline 2 & Boston, MA & 2011 & 49 & 121 & 72 & $239^{2}$ & 1,586 \\
\hline 3 & Denver, CO & 2010 & 0 & 0 & 36 & 36 & 152 \\
\hline 4 & Miami, FL & 2009 & 22 & 4 & $24^{3}$ & 50 & 26 \\
\hline 5 & $\begin{array}{l}\text { Minneapolis-St. Paul, } \\
\text { MN }\end{array}$ & 2010 & 0 & 4 & 16 & 20 & 97 \\
\hline 6 & Portland, OR & 2011 & 0 & 7 & 87 & 94 & 304 \\
\hline 7 & Salt Lake City, UT & 2012 & 0 & 1 & 36 & 37 & 114 \\
\hline 8 & Seattle, WA & 2006 & 0 & 11 & 25 & $35^{2}$ & 16 \\
\hline & Total & & 109 & 148 & 272 & 549 & 2,433 \\
\hline
\end{tabular}

1) This study includes only transit stations that had opened before the survey year.

2) The total stations is not equal to the sum of each row because some stations serve two or more types of transit.

3) Miami’s People Mover, an automated guideway transit, is included under the LRT category.

\subsection{DATA}

Following the definition of TOD and the literature review, this study classifies station areas by activity density, land use diversity and walkability. Activity density is the sum of population and employment for traffic analysis zones (TAZs), acquired from regional MPO data, divided by gross land area (Ewing et al., 2015). For land use diversity, we computed an entropy index. Each region provided parcel maps so that we could calculate the proportion of the area of each land use type_-residential, commercial, and public_-in a half-mile buffer from each station. For 
the "walkability" variable, we computed the number of intersections per square mile from street network shapefiles. Because these three built-environment variables_activity density, land use entropy, and intersection density — vary in range, we scaled the data by standardizing each variable to a mean of 0 and a standard deviation of 1 .

Although distance to transit is not included as a classifying factor, we measured it as a network distance from a household to the rail station because that might be an important determinant of transit trips. Also, regional accessibility is another important variable to predict travel behaviors (Ewing et al., 2015). The regional accessibility to employment is the percentage of jobs that could be reached within 10 minutes by automobile, which tends to be highest at central locations and lowest at peripheral ones. We used travel time skims and TAZ-level employment data acquired from regional MPOs.

From the travel survey data in eight regions, we calculated automobile trips, vehicle miles traveled (VMT), transit trips, and walk trips by individual households. The survey data have exact XY coordinates so the researchers could geocode the precise locations of residences and measure the lengths of trips, although the use of the minimum possible path between two trip ends might underestimate the exact VMT of the trips travelers actually take (Ewing, Hamidi and Grace, 2016). The survey data include demographic variables such as household size, the number of employed, household income, and the number of personal vehicles per person. The number of households living within a half-mile of stations and included in the household travel surveys was 2,433 in the eight regions.

\subsection{RESEARCH PROCESS AND METHODS}

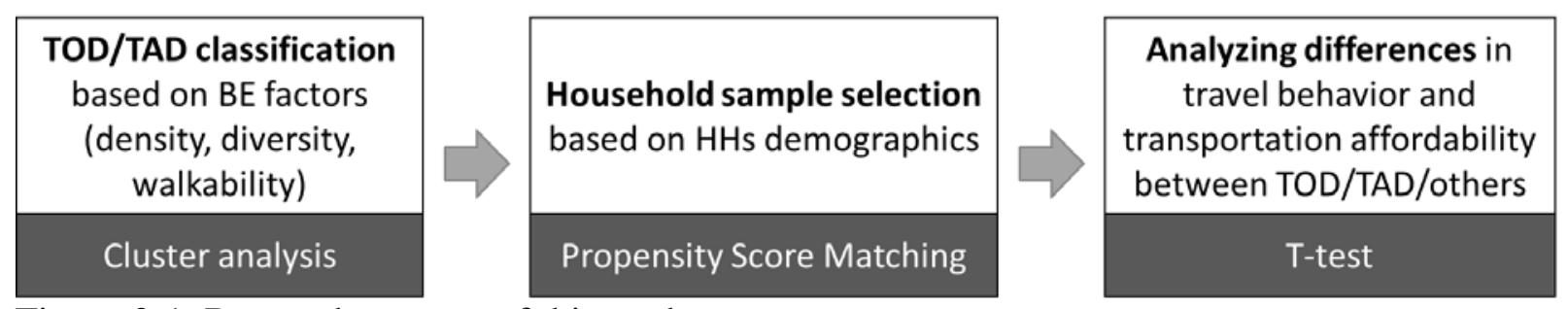

Figure 3-1. Research process of this study

This study consists of three steps. Although detailed explanations of each step will be followed, we present the whole picture here briefly. First, we classify station areas based on three builtenvironment characteristics - density, diversity, and walkability - as the literature suggests. Second, from the household travel surveys, we select household samples living in each type of station area. As the households could be significantly different among station area types and it could make it hard to evaluate the true impact of built environment on travel behavior, this study utilizes propensity score matching method in order to make samples comparable and thus, control residential self-selection. Finally, this study compares travel outcomes among different station area types, and computes household transportation cost using actual travel survey data. The transportation affordability is compared among TOD, TAD and other types. 


\subsubsection{Step 1. TOD/TAD classification: Cluster analysis}

Because the built environments around transit stations fall within a TOD-TAD spectrum, not a simple dichotomous scale, and there is no certain agreement of ideal built environments for TOD, identifying TODs and distinguishing them from TADs could be a difficult but important research step. Cluster analysis has been a preferred method for generating TOD typologies in previous studies (Atkinson-Palombo and Kuby, 2011; Kamruzzaman et al., 2014; Vale, 2015).

Using cluster analysis, this study classifies station area types based on three built-environment factors - density, land use diversity, and walkability. This approach groups existing station areas based on the actual characteristics of their built environments, rather than theoretical criteria of TOD or TAD. To be specific, this study uses a hierarchical clustering algorithm with Ward D2 distance measure. To determine the optimal number of clusters in a data set, this study utilizes the "NbClust" package in R 3.3.1 software, which provides 26 validation indices of clustering, such as the Calinski and Harabasz index and the Silhouette index (Charrad et al., 2014).

\subsubsection{Step 2. Household sample selection: Propensity score matching}

Propensity score matching (PSM) has been widely used to overcome nonrandom assignment of treatment in the evaluation of social programs (Oakes and Johnson, 2006). Evaluation studies are often based on observational data, in which the assignment of treatment is not random.

Accordingly, individuals in the treatment group are likely to differ systematically from those in the control group. For example, households living in suburban regions could be more affluent than their counterparts in downtown, a result of residential self-selection. Therefore, observations of difference in behavioral outcomes between the groups are confounded by residential selfselection. Statistically, it generates a biased estimate of treatment effect.

The propensity score is defined as the conditional probability of assignment to a particular treatment given a vector of observed covariates (Rosenbaum and Rubin, 1984). In the context of TOD and TAD, the treated group is households living in TOD station areas while the control group is those living in either TAD or Hybrid areas.

The propensity score matching was implemented in R 3.3.1 using the MatchIt package. First, we develop a binary logit model to estimate a propensity score using the subsample of households living in TOD (treatment) and TAD (control). We chose household characteristics as independent variables - household size, the number of workers, household income, distance to the nearest transit station, regional job accessibility, and the regions_-as potential sources of residential self-selection and confounding factors in travel outcome. Because the PSM model is a prediction model, we do not need to check the statistical significance and multicollinearity of independent variables (Cao, $\mathrm{Xu}$ and Fan, 2010). Second, we match each household living in TODs with those in TADs based on the propensity score. A caliper length of 0.2 is used for matching as suggested by Austin (2009), meaning that for a treatment observation, we seek a match in control observations whose propensity scores are within 0.2 of the standard deviation of the score in the treatment observation. Third, we evaluate whether the TOD residents are 
systematically different from their matches in TADs. If they are different in terms of demographics, self-selection is still a concern. We use t-test to assess whether demographics and locational factors are balanced between the matched groups.

The final goal of PSM is to compute the "true" impact of TOD/TAD on travel behavior. Once the matching was complete, we calculated the average treatment effects (ATE) of station area type on VMT, transit trips, and walk trips. For the illustration example below, the ATE is computed as the mean travel factors of the matched TOD households minus those of the matched TAD households. The observed influence of living in TOD on travel behavior is same calculation but using the original samples in TOD and TAD before matching (see Figure 3-2). The ratio of ATE over the observed influence is the proportion of the observed difference that can be attributable to TOD/TAD itself.

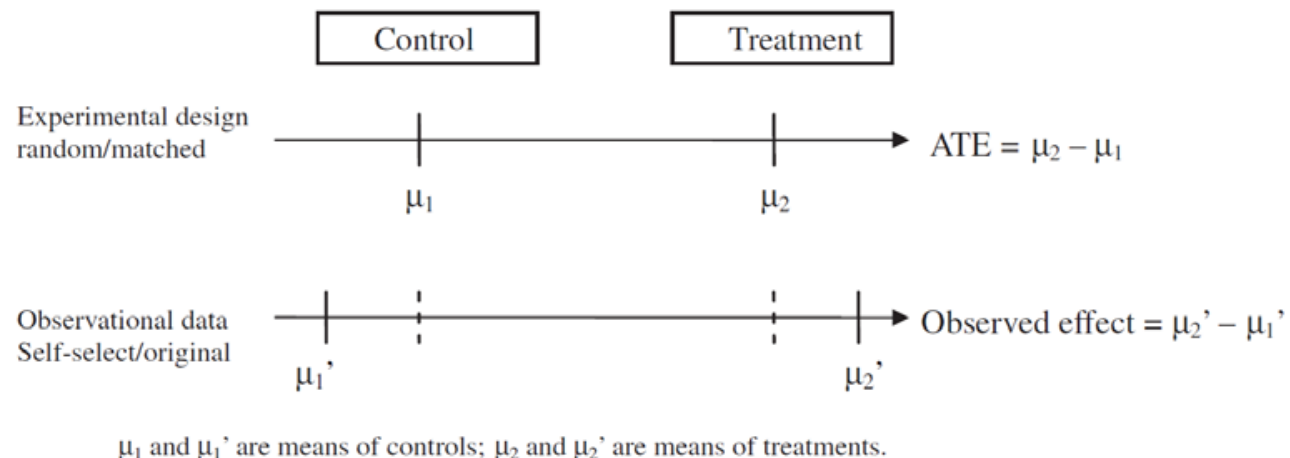

Figure 3-2. The relationship between observed effect and treatment effect (Cao, Xu and Fan, 2010)

Because this study has three area types_-TOD, TAD and Hybrid—in contrast to most studies with only one treatment and one control, this study applies PSM with multiple nominal treatments (Lechner, 2002). In this case, the propensity score can be estimated separately for each control-treatment pair. For each pair of locations, we estimated a binary logit model using the subsample containing respondents living in the locations.

\subsubsection{Step 3. Analysis of transportation affordability}

In this study, we estimate household transportation costs as the sum of vehicle costs (household's expenses to own and use private vehicles) and public transit costs (transit fares). Vehicle costs are divided into fixed and variable costs.

$$
\text { Household Transportation Costs }=C_{A O} \times F_{A O}(X)+C_{A U} \times F_{A U}(X)+C_{T U} \times F_{T U}(X)
$$

where $\mathrm{C}$ is a cost factor (i.e., dollars per mile) and $\mathrm{F}$ is a function of the independent variables ( $F_{A O}$ is auto ownership, $F_{A U}$ is auto use, and $F_{T U}$ is transit use). Fixed or ownership costs are not generally affected by the amount a vehicle is driven. Depreciation, insurance, and registration fees are considered fixed. Variable costs are the incremental costs that increase with vehicle mileage. Fuel is a variable vehicle cost; it is proportional to mileage (Lipman, 2006). 
We computed vehicle fixed costs based on our household vehicle ownership data and the average cost of car ownership specific to the most popular cars for each income bracket. Our average car ownership costs are based on the "True Cost to Own (TCO) pricing" system developed by Edmunds Inc. The components of TCO are depreciation, interest on financing, taxes and fees, insurance premiums, fuel, maintenance, repairs and any federal tax credit. In this study, we used all categories except fuel because we treat fuel as a variable vehicle cost.

We were interested in costs for the most popular vehicles' model and make for specific income levels. First, we selected all surveyed households in eight study regions from the National Household Travel Database (NHTS) and identified the 10 most popular vehicles for each of 18 income brackets classified by HUD (For the lowest and highest income brackets, see Table 3-2). Because TCO calculated the costs for cars made after 2009, the most similar model with the lowest edition was taken for older models. These popular vehicles account for about $30 \%$ of total vehicles in the eight regions in the NHTS database. While the average vehicle ownership cost moderately increases with income level, the difference is not huge. It is $\$ 4,278$ for the lowest income group and $\$ 4,464$ for the highest income group. Then this fixed cost per car for each income group is multiplied by the number of cars owned by a household in our travel survey data.

\section{Table 3-2. Top 10 automobiles and average ownership cost for lowest and highest income bracket in eight regions from NHTS and Edmunds Inc. data}

\begin{tabular}{|c|c|c|c|c|c|}
\hline \multirow{12}{*}{$\begin{array}{c}\text { Lowest income } \\
\text { bracket } \\
\text { (median annual } \\
\text { income = } \$ 2,500 \text { ) }\end{array}$} & $\begin{array}{l}\text { Make } \\
\text { name }\end{array}$ & Model name & $\begin{array}{c}\text { Annual } \\
\text { Ownership Cost } \\
\text { (except fuel cost) }\end{array}$ & $\begin{array}{l}\text { Sample } \\
\text { size }\end{array}$ & $\begin{array}{l}\text { Average Own Cost } \\
\text { (weighted by } \\
\text { sample \%) }\end{array}$ \\
\hline & Ford & F-Series pickup & $\$ 4,570$ & 14 & \multirow{11}{*}{$\$ 4,278$} \\
\hline & Chevrolet & $\begin{array}{l}\text { C, K, R, V-Series } \\
\text { pickup/Silverado }\end{array}$ & $\$ 5,243$ & 11 & \\
\hline & Ford & Range Supercab & $\$ 3,923$ & 10 & \\
\hline & Toyota & Camry & $\$ 3,470$ & 7 & \\
\hline & Dodge & $\begin{array}{l}\text { Caravan/Grand } \\
\text { Caravan }\end{array}$ & $\$ 3,787$ & 6 (tie) & \\
\hline & Ford & $\begin{array}{l}\text { Bronco/Explorer Sport } \\
\text { Trac }\end{array}$ & $\$ 5,297$ & 6 & \\
\hline & Buick & Century/Buick Regal & $\$ 3,989$ & 6 & \\
\hline & Chevrolet & Cavalier & $\$ 3,096$ & 6 & \\
\hline & Jeep & Cherokee & $\$ 5,121$ & 6 & \\
\hline & Ford & Taurus/Taurus X & $\$ 4,522$ & 5 (tie) & \\
\hline & Ford & Maverick & $\$ 3,051$ & 5 & \\
\hline \multirow{4}{*}{$\begin{array}{l}\text { Highest income } \\
\text { bracket } \\
\text { (median annual } \\
\text { income = over } \\
\mathbf{\$ 1 0 0 , 0 0 0 )}\end{array}$} & Ford & F-Series pickup & $\$ 4,570$ & 220 & \multirow{4}{*}{$\$ 4,464$} \\
\hline & Chevrolet & $\begin{array}{l}\text { C, K, R, V-Series } \\
\text { pickup/Silverado }\end{array}$ & $\$ 5,243$ & 124 & \\
\hline & Honda & Accord & $\$ 3,892$ & 105 & \\
\hline & Toyota & Camry & $\$ 3,470$ & 89 & \\
\hline
\end{tabular}




$\begin{array}{llcc}\text { Honda } & \text { Odyssey } & \$ 4,059 & 74 \\ \text { Ford } & \text { Bronco/Explorer Sport } & \$ 5,297 & 71 \\ & \text { Trac } & \$ 5,121 & 64 \\ \text { Jeep } & \text { Cherokee } & \$ 3,111 & 60 \text { (tie) } \\ \text { Honda } & \text { Civic/CRX, del Sol } & \$ 5,745 & 60 \\ \text { Ford } & \text { Expedition } & \$ 4,418 & 51 \text { (tie) } \\ \text { Dodge } & \text { Ram Pickup } & \$ 3,767 & 51 \\ \text { Toyota } & \text { Tacoma } & & \end{array}$

Second, we computed auto operating costs based on our household VMT data and gasoline price data specific to eight metropolitan regions. As illustrated in Table 3-3, average gasoline prices vary from region to region. We acquired metropolitan-level average gasoline prices for regular unleaded in 2010 from the Oil Price Information Service (OPIS) and then multiplied the fuel costs per gallon by the actual VMT to obtain the household's operating or variable vehicle costs.

\section{Table 3-3. Average gasoline price per gallon (2010) for eight regions}

$\begin{array}{ll}\text { Region } & \text { Gas Price (\$/gallon) } \\ \text { Atlanta, GA } & 2.83 \\ \text { Boston, MA } & 2.89 \\ \text { Denver, CO } & 2.75 \\ \text { Miami, FL } & 3.01 \\ \text { Minneapolis-St. Paul, MN } & 2.83 \\ \text { Portland, OR } & 3.02 \\ \text { Salt Lake City, UT } & 2.94 \\ \text { Seattle, WA } & 3.15\end{array}$

Third, we compute transit costs based on our household transit trip data and average transit fares specific to the regions (Table 3-4). Transit fare data come from the National Transit Database. We computed average transit fare for each region by dividing the total transit revenue by total number of unlinked passenger trips for the region. We multiplied the amount of fare per transit trip by the actual number of transit trips to obtain the household’s public transit costs.

Table 3-4. Average transit fare (2010) for eight regions

$\begin{array}{ll}\text { Region } & \text { Transit fare (\$) } \\ \text { Atlanta, GA } & 0.82 \\ \text { Boston, MA } & 1.26 \\ \text { Denver, CO } & 1.03 \\ \text { Miami, FL } & 0.96 \\ \text { Minneapolis-St. Paul, MN } & 1.14 \\ \text { Portland, OR } & 0.93\end{array}$


$\begin{array}{ll}\text { Salt Lake City, UT } & 0.92 \\ \text { Seattle, WA } & 1.37\end{array}$

To estimate the overall household's transportation costs for each property in our sample, we added up the three transportation cost components. Finally, we calculated the percentage of a household's income spent on transportation-i.e. transportation affordability—-for sample households in each station area type. 


\subsection{TOD/TAD CLASSIFICATION: CLUSTER ANALYSIS}

By using the NbClust package in R 3.3.1 software, which generates 26 validation indices of clustering, this study could determine the optimal number of clusters in the data set. As a result, thirteen of the 26 indices suggest that three is the optional number of clusters.

Table 4-1 shows the result of hierarchical clustering. The first cluster ( $n=107)$ is titled "TAD." It has the lowest levels of activity density, land use diversity and intersection density. The second and largest cluster (n=382), "Hybrid," has low levels of activity density and intersection density, but the highest land use entropy index. The final cluster (n=60), “TOD,” has the highest activity density and intersection density, and a high level of land use mix. Figure 4-1 shows representative stations in each cluster. The stations are selected for values closest to the median on each of the three classifying factors.

Table 4-1. Cluster analysis result and descriptive statistics

\begin{tabular}{|c|c|c|c|c|c|c|c|}
\hline \multirow[t]{2}{*}{$\begin{array}{l}\text { Cluster } \\
\text { type }\end{array}$} & \multirow{2}{*}{$\begin{array}{c}\text { Number } \\
\text { of } \\
\text { Stations }\end{array}$} & \multicolumn{2}{|c|}{$\begin{array}{l}\text { Activity Density } \\
\text { (/sq.mi.) }\end{array}$} & \multicolumn{2}{|c|}{ Entropy Index } & \multicolumn{2}{|c|}{$\begin{array}{c}\text { Intersection Density } \\
\text { (/sq.mi.) }\end{array}$} \\
\hline & & Mean & S.D. & Mean & S.D. & Mean & S.D. \\
\hline TAD & 107 & 10,319 & 11,751 & 0.30 & 0.19 & 110 & 58 \\
\hline Hybrid & 382 & 21,210 & 19,764 & 0.75 & 0.15 & 194 & 79 \\
\hline TOD & 60 & 135,327 & 51,025 & 0.70 & 0.24 & 386 & 110 \\
\hline TOTAL & 549 & 31,559 & 43,821 & 0.66 & 0.24 & 199 & 108 \\
\hline
\end{tabular}




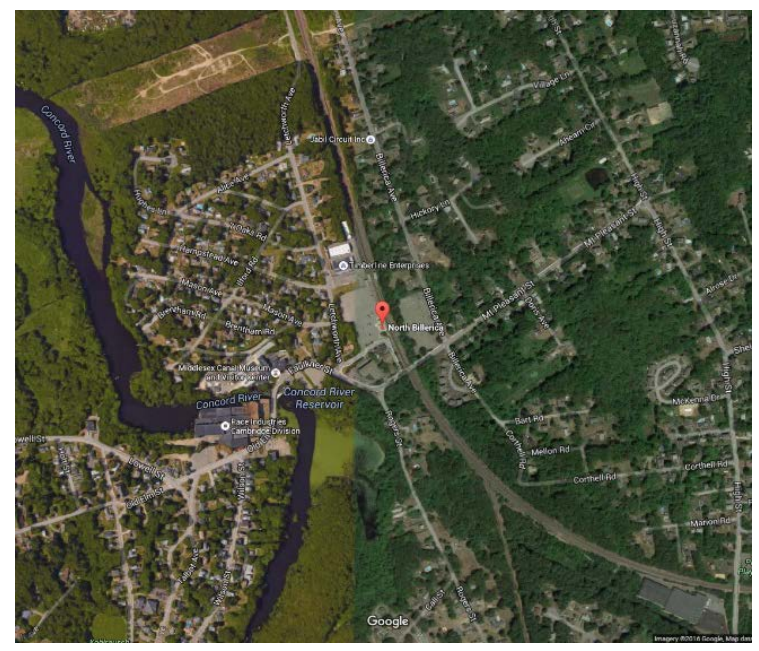

1) TAD type: North Billerica Station, Boston

- Population ( $1 \frac{1}{2}$ mile): 548

- Employment (1/2 mile): 420

- Activity Density: 2,384/sq. mi.

- $\quad$ Land Use Entropy: 0.30

- Residential 55\%, Commercial 1\%, Public 3\%

- Intersection density: 118/sq. mi.

- Transit Stop density: 7/sq. mi.

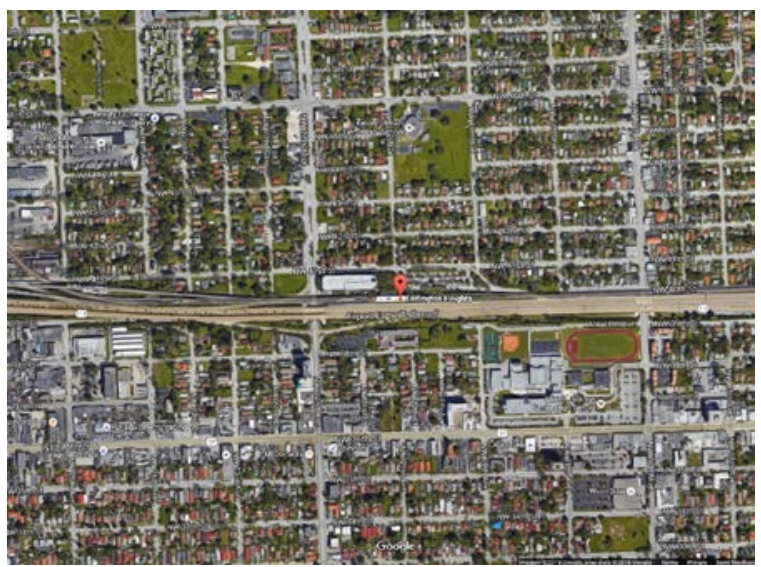

2) Hybrid type: Earlington Heights Station, Miami

- Population ( $1 / 2$ mile): 2,965

- Employment (1/2 mile): 1,205

- Activity Density: $11,003 / \mathrm{sq}$. mi.

- Land Use Entropy: 0.78

- Residential 53\%, Commercial 9\%, Public 19\%

- Intersection density: 198/sq. mi.

- Transit Stop density: 74/sq. mi.

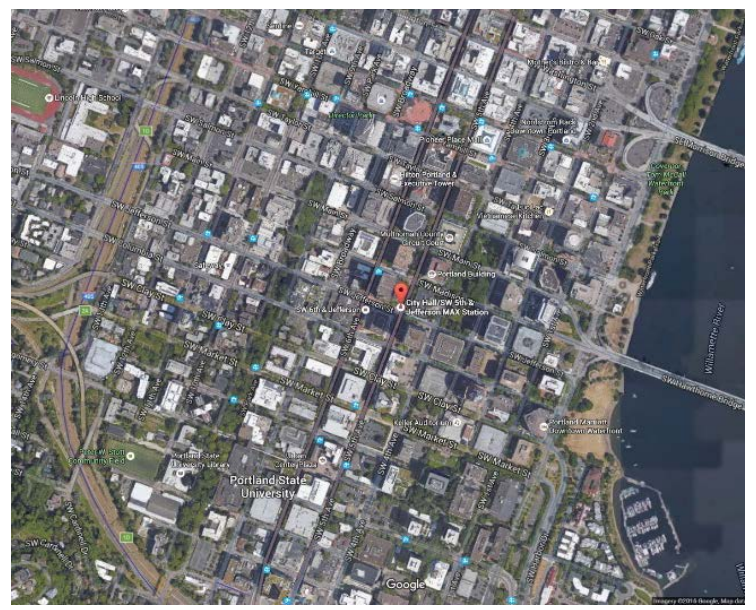

3) TOD type: City Hall/SW $5^{\text {th }}$ Ave. and Jefferson St. MAX Station, Portland

- Population ( $1 \frac{12}{2}$ mile): 7,412

- Employment (1/2 mile): 43,614

- Activity Density: $112,145 /$ sq. mi.

- Land Use Entropy: 0.71

- Residential 14\%, Commercial 62\%, Public $10 \%$

- Intersection density: 393/sq. mi.

- Transit Stop density: 705/sq. mi.

Figure 4-1. Examples of each station area type (Image Source: Google Maps)

Sample households were selected as those living within a half-mile, network distance, from stations. We allotted individual households to their nearest stations based on network distance in order to assign the station types. TAD type has 251 sample households while TOD and Hybrid type have 306 and 1,876 households, respectively (Table 4-2). 
Table 4-2 shows that households living in TADs have more household members, more employed members, and higher incomes than those living in TODs or Hybrids. ANOVA analysis shows that the differences are significant. Regarding travel behavior, TAD households have much higher VMT and daily auto trips, and lower daily transit and walk trips, than those in TODs or Hybrids. The average Hybrid-area household is in the middle on five of the seven measurements, the exceptions being their low household incomes and high number of transit trips. Personal vehicle travel accounts for two-thirds of total trips in TADs but only a quarter of total trips in TODs (Figure 4-2).

Post-hoc comparisons using Tukey's Honest Significant Difference (HSD) method show that the three groups are significantly different from each other in VMT, auto trips, and walk trips variables. TAD and Hybrid show no significant difference in household size and worker variables, while TOD and Hybrid are similar in terms of transit trips (Table 4-2).

Table 4-2. Household characteristics and travel behavior by station area types: average and ANOVA analysis

\begin{tabular}{|c|c|c|c|c|c|c|c|c|c|}
\hline $\begin{array}{l}\text { Cluster } \\
\text { type }\end{array}$ & $\begin{array}{c}\text { No. of } \\
\text { Stations }\end{array}$ & $\begin{array}{c}\text { HH } \\
\text { samples }\end{array}$ & $\begin{array}{l}\text { HH } \\
\text { size }\end{array}$ & $\begin{array}{c}\text { HH } \\
\text { workers }\end{array}$ & $\begin{array}{c}\text { HH } \\
\text { Income } \\
(\$ 1,000) \\
(2010)\end{array}$ & VMT & $\begin{array}{l}\text { Daily } \\
\text { Auto } \\
\text { Trips }\end{array}$ & $\begin{array}{c}\text { Daily } \\
\text { Transit } \\
\text { Trips }\end{array}$ & $\begin{array}{l}\text { Daily } \\
\text { Walk } \\
\text { Trips }\end{array}$ \\
\hline TAD & 107 & 251 & 2.19 & 1.28 & 83.72 & 21.23 & 6.06 & 0.72 & 1.91 \\
\hline Hybrid & 382 & 1,876 & 2.15 & 1.22 & $\begin{array}{l}77.02 \\
\end{array}$ & 15.44 & 4.93 & 1.47 & 3.89 \\
\hline TOD & 60 & 306 & 1.54 & 0.97 & 82.02 & 8.61 & 2.04 & 1.35 & 4.81 \\
\hline Total & 549 & 2,433 & 2.07 & 1.19 & 78.34 & 15.18 & 4.68 & 1.37 & 3.80 \\
\hline $\begin{array}{l}\text { F- } \\
\text { statistic } \\
\text { (ANOVA) }\end{array}$ & - & - & $\begin{array}{r}37.23 \\
* * *\end{array}$ & $\begin{array}{l}14.1 \\
* * *\end{array}$ & $\begin{array}{r}2.37 \\
*\end{array}$ & $\begin{array}{r}32.00 \\
* * *\end{array}$ & $\begin{array}{r}47.19 \\
* * *\end{array}$ & $\begin{array}{r}12.42 \\
* * *\end{array}$ & $\begin{array}{r}30.37 \\
* * *\end{array}$ \\
\hline $\begin{array}{l}\text { Different } \\
\text { pairs } \\
\text { (post-hoc } \\
\text { test) }\end{array}$ & - & - & $\begin{array}{l}\text { TOD- } \\
\text { TAD; } \\
\text { TOD- } \\
\text { Hybrid }\end{array}$ & $\begin{array}{l}\text { TOD- } \\
\text { TAD; } \\
\text { TOD- } \\
\text { Hybrid }\end{array}$ & none & all & all & $\begin{array}{l}\text { TOD- } \\
\text { TAD; } \\
\text { TAD- } \\
\text { Hybrid }\end{array}$ & all \\
\hline
\end{tabular}




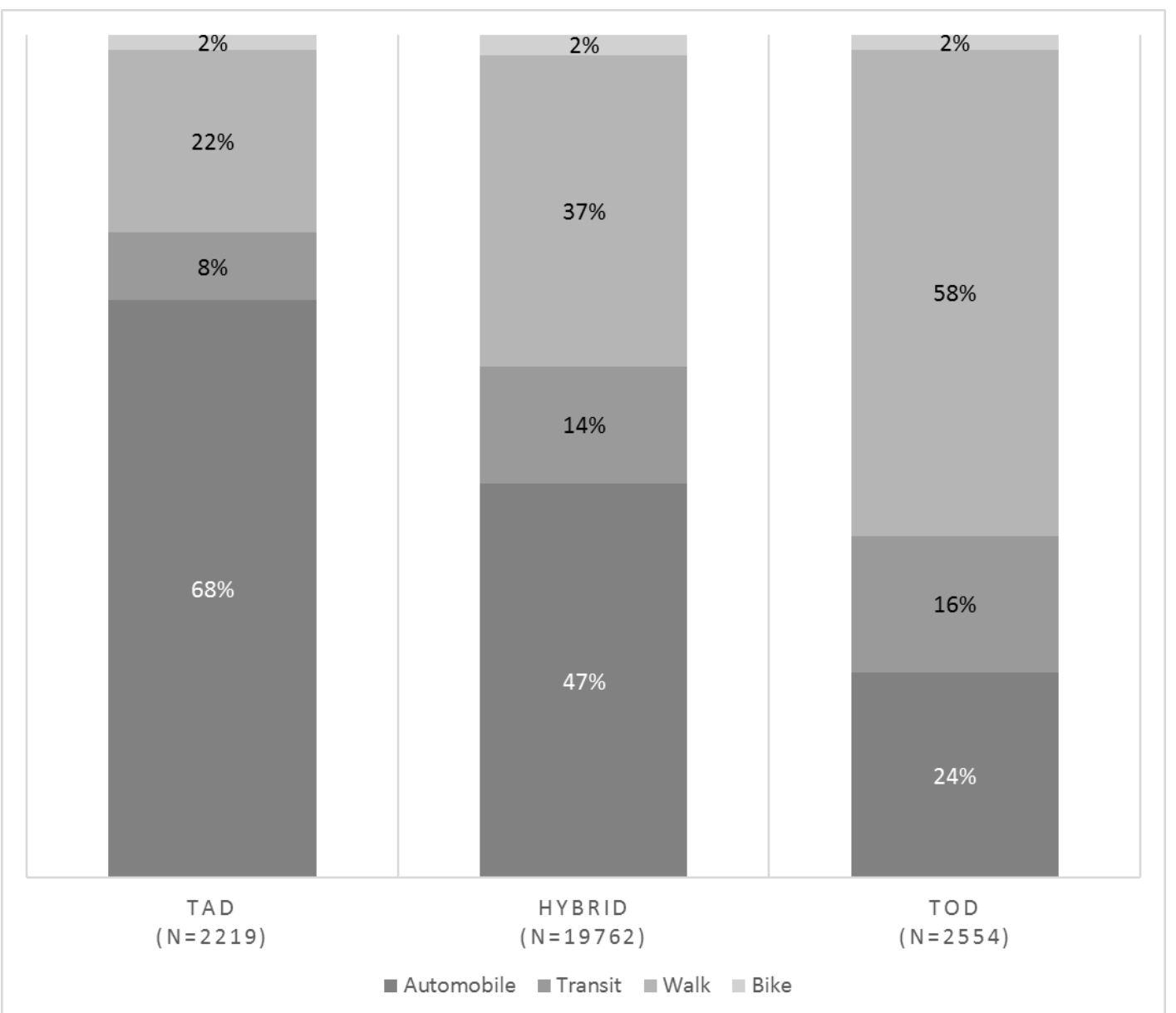

Figure 4-2. Mode Share by Station Area Type (n is total number of trips in each area type) 


\subsection{TRAVEL BEHAVIOR IN TOD VS. TAD HOUSEHOLDS: PROPENSITY SCORE MATCHING}

As shown above, in the context of station areas, households living in TADs tend to be more affluent, have more cars, have more members, and be more auto-oriented than their counterparts in TODs. Residential self-selection theory says, however, that the TAD households might live there because they are auto-oriented. Therefore, the true difference in travel outcomes between TODs and TADs is estimated here by matching samples using PSM.

With the six explanatory variables-household size, the number of workers, household income, distance to nearest transit station, regional job accessibility, and the regions, household pairs in three area-type pairs (TOD-TAD, TOD-Hybrid, and TAD-Hybrid) are matched. The PSM generates 54 household pairs (108 households total) in TOD-TAD, 175 pairs in TOD-Hybrid and 182 pairs in TAD-Hybrid.

After matching, we first evaluate whether the chosen residents in one type are systematically different from those in another type. If they are different in terms of demographics, self-selection is still a concern. Table 5-1 shows differences of household characteristics before and after matching. Unlike for unmatched samples, t-test results for matched samples show that TOD and TAD residents do not differ by all covariates. Those variables are not statistically different in both TOD-Hybrid and TAD-Hybrid pairs as well (results are not shown).

Table 5-1. Mean differences of observed covariates between TOD and TAD in unmatched and matched samples

\begin{tabular}{|c|c|c|c|c|c|c|c|}
\hline \multirow{2}{*}{\multicolumn{2}{|c|}{ Variables }} & \multicolumn{3}{|c|}{ Before Matching } & \multicolumn{3}{|c|}{ After Matching } \\
\hline & & $\begin{array}{c}\text { TAD } \\
(n=251)\end{array}$ & $\begin{array}{c}\text { TOD } \\
(n=306)\end{array}$ & $\begin{array}{c}\text { Mean } \\
\text { Difference }{ }^{1)}\end{array}$ & $\begin{array}{c}\text { TAD } \\
(n=54)\end{array}$ & $\begin{array}{c}\text { TOD } \\
(n=54)\end{array}$ & $\begin{array}{c}\text { Mean } \\
\text { difference }^{1}\end{array}$ \\
\hline \multicolumn{2}{|c|}{ Household size } & 2.19 & 1.54 & $0.65^{* * *}$ & 1.50 & 1.52 & -0.02 \\
\hline \multicolumn{2}{|c|}{ Household workers } & 1.28 & 0.97 & $0.31^{* * *}$ & 1.04 & 1.02 & 0.02 \\
\hline \multicolumn{2}{|c|}{ Household income $(\$ 1,000)$} & 83.72 & 82.02 & 1.70 & 72.19 & 76.34 & -4.15 \\
\hline \multicolumn{2}{|c|}{ Distance to station (miles) } & 0.33 & 0.28 & $0.05^{* * *}$ & 0.32 & 0.33 & -0.01 \\
\hline \multicolumn{2}{|c|}{ Regional job accessibility } & 9.89 & 19.04 & $-9.15 * * *$ & 15.98 & 16.76 & -0.78 \\
\hline \multirow{5}{*}{$\begin{array}{l}\text { Number of } \\
\text { Station } \\
\text { Areas } \\
\text { by Region }{ }^{2}\end{array}$} & Atlanta & 32 & 12 & - & 10 & 9 & - \\
\hline & Boston & 75 & 204 & - & 7 & 9 & - \\
\hline & Denver & 40 & 29 & - & 17 & 18 & - \\
\hline & Minneapolis & 67 & 23 & - & 17 & 14 & - \\
\hline & Portland & 31 & 38 & - & 3 & 4 & - \\
\hline
\end{tabular}

1) ${ }^{* * *}: \mathrm{p}<.01,{ }^{* *}: \mathrm{p}<.5, *: \mathrm{p}<.1$ (T-test results)

2) Miami, Salt Lake City, and Seattle are dropped because no matched samples were found. 
The final goal of PSM is to compute the "true" impact of station area type on travel behavior. Once the matching was complete, we calculated the average treatment effects (ATE), the observed differences, and the ratio between them on VMT, auto trips, transit trips and walk trips for each area pair. As an example, the observed difference of the TOD-TAD pair is the mean travel factors of all TOD households minus that of all TAD households in the original sample. The ATE is the difference in mean travel factors between the matched samples.

In Table 5-2, the third to seventh columns show, respectively, observed difference in mean in the original sample, ATE in matched sample, ratio of ATE over observed difference, mean value of control group after matching (the control group is TAD in the first and third pair and Hybrid in the second pair), and ratio of ATE over control mean. Regarding VMT in TOD-TAD pairs, after matching (i.e., controlling for residential self-selection), TAD households tend to drive 5.49 miles per day more than TOD residents. The significant effect on VMT of living in a TOD accounts for approximately $87 \%$ of the observed influence; that is, $13 \%$ of the observed difference may result from residential self-selection.

In addition, the mean difference in daily automobile trips between matched TAD and TOD households is 1.44 and statistically significant. That is, if a randomly selected household moves from a TAD to a TOD, we expect a decrease in driving by 1.44 trips per day. The effect on auto trips of living in TOD accounts for approximately 36\% of the observed influence, meaning that the rest 64\% may result from unobserved factors such as self-selection. On average, the matched sample households in TAD drove 4.06 times per day. Thus, the effect of living in TOD itself represents a considerable $35 \%$ decrease (1.44 fewer trips) in daily auto trips.

In addition, the probability of walking or taking transit significantly decreases from TOD to TAD. After matching, an average household living in a TOD takes 0.74 more transit trips (a $148 \%$ increase) than its pair in a TAD. Likewise, the average household in a TOD takes 1.89 more walk trips (a 110\% increase) than its pair in a TAD, and both differences are statistically significant.

When we compare Hybrid areas to TODs, the number of daily auto trips is significantly higher (0.84 more) and the number of walk trips is significantly lower (1.20 fewer) in Hybrid areas. The effect of living in TOD itself represents a $27 \%$ decrease in daily auto trips and a $30 \%$ increase in daily walk trips, compared to living in a Hybrid area. VMT and transit trips are not significantly different between Hybrid and TOD areas.

In the TAD-Hybrid pair, auto trips are not significantly different. Differences on VMT, walk trips, and transit trips are slightly significant. Compared to TAD areas, VMT is lower (3.75 fewer miles), the number of daily transit trips is higher (0.35 more), and the number of daily walk trips is higher ( 0.75 more) in Hybrid areas. The effect of living in a Hybrid area itself represents a $16 \%$ decrease in VMT, a $48 \%$ increase in transit trips, and a $36 \%$ increase in walk trips, compared to living in a TAD. 
Table 5-2. Differences in travel behavior between station area types after matching

\begin{tabular}{|c|c|c|c|c|c|c|}
\hline Area Type Pair & $\begin{array}{c}\text { Travel } \\
\text { outcomes }\end{array}$ & $\begin{array}{c}\text { Observed } \\
\text { difference } \\
\text { (original } \\
\text { sample) }\end{array}$ & $\begin{array}{c}\text { ATE } \\
\text { (difference } \\
\text { after matching) }\end{array}$ & $\begin{array}{l}\text { ATE/observed } \\
\text { difference } \\
\text { ratio }\end{array}$ & $\begin{array}{l}\text { Mean of } \\
\text { Control } \\
\text { Group }\end{array}$ & $\begin{array}{l}\text { ATE/ } \\
\text { control } \\
\text { ratio }\end{array}$ \\
\hline \multirow{4}{*}{$\begin{array}{c}\text { TAD (control) } \\
- \text { TOD } \\
\text { n=557 (unmatched), } \\
\text { n=108 (matched) }\end{array}$} & VMT & $6.34 * * *$ & $5.49 * *$ & 0.87 & 14.18 & 0.39 \\
\hline & Auto trips & $4.02^{* * *}$ & $1.44^{* *}$ & 0.36 & 4.06 & 0.35 \\
\hline & $\begin{array}{c}\text { Transit } \\
\text { trips }\end{array}$ & $-0.64 * * *$ & $-0.74 * * *$ & 1.16 & 0.50 & -1.48 \\
\hline & Walk trips & $-2.86^{* * *}$ & $-1.89 * * *$ & 0.66 & 1.72 & -1.10 \\
\hline \multirow{4}{*}{$\begin{array}{c}\text { Hybrid (control) } \\
\text { - TOD } \\
\text { n=2,182 } \\
\text { (unmatched), } \\
\text { n=350 (matched) }\end{array}$} & VMT & $3.64^{* * *}$ & 0.48 & 0.13 & 9.53 & 0.05 \\
\hline & Auto trips & $2.87^{* * *}$ & $0.84 * *$ & 0.29 & 3.10 & 0.27 \\
\hline & $\begin{array}{c}\text { Transit } \\
\text { trips }\end{array}$ & 0.11 & -0.12 & -1.09 & 1.39 & -0.09 \\
\hline & Walk trips & $-0.89 * * *$ & $-1.20 * * *$ & 1.35 & 3.95 & -0.30 \\
\hline \multirow{2}{*}{$\begin{array}{c}\text { TAD (control) } \\
\text {-Hybrid }\end{array}$} & VMT & $2.70 * *$ & $3.75^{*}$ & 1.39 & 23.69 & 0.16 \\
\hline & Auto trips & $1.15^{* * *}$ & 0.00 & 0.00 & 6.70 & 0.00 \\
\hline \multirow{2}{*}{$\begin{array}{c}\mathrm{n}=2,127 \\
\text { (unmatched), } \\
\mathrm{n}=364 \text { (matched) }\end{array}$} & $\begin{array}{c}\text { Transit } \\
\text { trips } \\
\end{array}$ & $-0.75 * * *$ & $-0.35 *$ & 0.47 & 0.73 & -0.48 \\
\hline & Walk trips & $-1.97 * * *$ & $-0.75^{*}$ & 2.08 & 2.08 & -0.36 \\
\hline
\end{tabular}

$* * *: \mathrm{p}<.01, * *: \mathrm{p}<.5, *: \mathrm{p}<.1$ (paired T-test results)

From the results of travel outcomes between three pairs of station area type, we could examine the gradual and cumulative changes. When a household moves from a TAD type to a Hybrid type, or a local government improves a TAD to a Hybrid by increasing its density, land use mix, or walkability, the average household is expected to have slightly shorter auto trips and more walk trips and transit trips. Then, if the household moves to a TOD, or the station area is developed to a TOD, the household is expected to have fewer auto trips and more walk trips. Cumulatively, from a TAD to a TOD, a household is estimated to have significantly shorter and fewer auto trips and more transit and walk trips. 


\subsection{TRANSPORTATION AFFORDABILITY IN TOD VS. TAD HOUSEHOLDS}

Household transportation costs consist of three components of travel behavior-vehicle ownership, vehicle use, and transit use (Haas et al., 2008; Hickey et al., 2012). From the original data before matching, the average income is $\$ 78,341$ (table 6-1). The average household spends $\$ 4,532$ for vehicle ownership, $\$ 747$ for vehicle use, and $\$ 600$ for transit use. Thus, total transportation cost is $\$ 5,879$ for the average household, which is $12.5 \%$ of yearly household income. Yearly transportation costs vary from $\$ 4,217$ in TOD areas to $\$ 6,411$ in TAD areas, with a gap of $\$ 2,194$. Likewise, transportation affordability percentages range from $8.6 \%$ in TOD to $13.3 \%$ in Hybrid. Hybrid type is least affordable as it has lowest average household income. All of the differences in transportation cost and affordability are statistically significant.

The overall transportation cost in this study is much smaller than in previous studies. Haas et al. (2008), for example, estimate that the average percentage of household income spent on transportation is $20.1 \%$ for median-income households in the U.S. This difference might be mainly attributable to the fact that this study deals only with station areas while the previous studies cover entire metro areas.

Table 6-1. Differences in transportation cost and affordability before matching $(n=2,433)$

$\begin{array}{ccccccc}\text { Type } & \text { Income } & \begin{array}{c}\text { Vehicle } \\ \text { Ownership } \\ \text { cost }\end{array} & \begin{array}{c}\text { Vehicle } \\ \text { Use } \\ \text { cost }\end{array} & \begin{array}{c}\text { Transit } \\ \text { cost }\end{array} & \begin{array}{c}\text { Total } \\ \text { Transportation } \\ \text { cost }\end{array} & \begin{array}{c}\text { Transportation } \\ \text { Affordability }\end{array} \\ \begin{array}{c}\text { TAD } \\ (\mathrm{n}=251)\end{array} & \$ 83,717 & \$ 5,096 & \$ 1,033 & \$ 282 & \$ 6,411 & 11.4 \% \\ \begin{array}{c}\text { TOD } \\ (\mathrm{n}=306)\end{array} & \$ 82,023 & \$ 3,218 & \$ 422 & \$ 577 & \$ 4,217 & 8.6 \% \\ \begin{array}{c}\text { Hybrid } \\ (\mathrm{n}=1,876)\end{array} & \$ 77,021 & \$ 4,670 & \$ 762 & \$ 647 & \$ 6,078 & 13.3 \% \\ \text { Average } & \$ 78,341^{*} & \$ 4,532^{* * *} & \$ 747^{* * *} & \$ 600^{* * *} & \$ 5,879^{* * *} & 12.5 \% * * * \\ * * *: \mathrm{p}<.01, * *: \mathrm{p}<.5, *: \mathrm{p}<.1 \text { (ANOVA test results) } & & & \end{array}$


After matching, the difference in transportation affordability between TAD and TOD areas is slightly significant (Table 6-2). Average TAD households spend 15.6\% after matching while average TOD households spend less than half of that-7.5\%. Higher spending on transit in TOD is cancelled out by lower spending on vehicle ownership and maintenance. Overall, matched households in both types spend about five thousand dollars a year for transportation, which accounts for $11.5 \%$ of income.

Table 6-2. Differences in transportation cost and affordability after matching: TOD-TAD pairs $(\mathbf{n}=108)$

$\begin{array}{ccccccc}\text { Type } & \text { Income } & \begin{array}{c}\text { Vehicle } \\ \text { Ownership } \\ \text { cost }\end{array} & \begin{array}{c}\text { Vehicle } \\ \text { Use } \\ \text { cost }\end{array} & \begin{array}{c}\text { Transit } \\ \text { cost }\end{array} & \begin{array}{c}\text { Total } \\ \text { Transportation } \\ \text { cost }\end{array} & \begin{array}{c}\text { Transportation } \\ \text { Affordability }\end{array} \\ \text { TAD } & \$ 72,194 & \$ 4,332 & \$ 679 & \$ 198 & \$ 5,209 & 15.6 \% \\ \text { TOD } & \$ 76,340 & \$ 3,799 & \$ 418 & \$ 481 & \$ 4,697 & 7.5 \% \\ \text { Average } & \$ 74,267 & \$ 4,065 & \$ 548 * * & \$ 340^{* *} & \$ 4,953 & 11.5 \% * \\ * * *: \mathrm{p}<.01, * *: \mathrm{p}<.5, *: \mathrm{p}<.1 \text { (paired T-test results) } & & & & \end{array}$

On the other hand, in the Hybrid-TOD pair, t-test result shows that neither the transportation cost nor the affordability percentage is significantly different between the two areas (Table 6-3). As a result, matched households in both types spend about $\$ 4,168$ a year for transportation, which accounts for $9.0 \%$ of income.

Table 6-3. Differences in transportation cost and affordability after matching: TODHybrid pairs $(n=350)$

$\begin{array}{ccccccc}\text { Type } & \text { Income } & \begin{array}{c}\text { Vehicle } \\ \text { Ownership } \\ \text { cost }\end{array} & \begin{array}{c}\text { Vehicle } \\ \text { Use } \\ \text { cost }\end{array} & \begin{array}{c}\text { Transit } \\ \text { cost }\end{array} & \begin{array}{c}\text { Total } \\ \text { Transportation } \\ \text { cost }\end{array} & \begin{array}{c}\text { Transportation } \\ \text { Affordability }\end{array} \\ \text { Hybrid } & \$ 70,144 & \$ 2,862 & \$ 464 & \$ 573 & \$ 3,899 & 9.0 \% \\ \text { TOD } & \$ 77,994 & \$ 3,366 & \$ 443 & \$ 628 & \$ 4,438 & 8.9 \% \\ \text { Average } & \$ 74,069 & \$ 3,114 & \$ 453 & \$ 600 & \$ 4,168 & 9.0 \% \\ * * *: p<.01, * *: \mathrm{p}<.5, *: \mathrm{p}<.1 \text { (paired T-test results) } & & & & \end{array}$


In the TAD-Hybrid pair, only transit spending shows a significant difference, being higher in Hybrid areas (Table 6.4). As a result, matched households in both types spend about seven thousand dollars a year for transportation, which accounts for $12.2 \%$ of income.

Table 6-4. Differences in transportation cost and affordability after matching: TADHybrid pairs $(n=364)$

$\begin{array}{ccccccc}\text { Type } & \text { Income } & \begin{array}{c}\text { Vehicle } \\ \text { Ownership } \\ \text { cost }\end{array} & \begin{array}{c}\text { Vehicle } \\ \text { Use } \\ \text { cost }\end{array} & \begin{array}{c}\text { Transit } \\ \text { cost }\end{array} & \begin{array}{c}\text { Total } \\ \text { Transportation } \\ \text { cost }\end{array} & \begin{array}{c}\text { Transportation } \\ \text { Affordability }\end{array} \\ \text { TAD } & \$ 88,906 & \$ 5,688 & \$ 1,159 & \$ 283 & \$ 7,130 & 11.6 \% \\ \text { Hybrid } & \$ 82,791 & \$ 5,242 & \$ 979 & \$ 456 & \$ 6,677 & 12.8 \% \\ \text { Average } & \$ 85,480 & \$ 5,465 & \$ 1,069 & \$ 369 * * & \$ 6,903 & 12.2 \% \\ * * *: \mathrm{p}<.01, * *: \mathrm{p}<.5, *: \mathrm{p}<.1 \text { (paired T-test results) } & & & & \end{array}$

Unlike the travel behavior results, transportation affordability has no gradual effects-from TAD to Hybrid or from Hybrid to TOD. Only TAD-TOD pairs show a marginally significant difference in the percentage of household income spent on transportation. This result shows that when a household moves from a TAD to a TOD, or an existing TAD-type station area becomes a TOD, the household is likely to save money on vehicle ownership and use while spending more on transit, which balances out to significant financial savings on transportation.

\subsection{CONCLUSION}

The clustering approach in this study classified existing station areas into TOD, TAD, and Hybrid types in terms of built-environment factors-density, diversity, and walkability. As a result, 11\% of the 549 stations in eight regions were labeled TOD, being dense, diverse, and walkable. One-fifth were named TAD, having the opposite urban form of TOD. The remaining $70 \%$ of the stations could be classified as Hybrid. Land use mix was a key factor to distinguish TAD from Hybrid while density and intersection density played important roles to differentiate TOD and Hybrid.

Station area types vary in the literature according to classifying methods, factors and regions. This study has an advantage in considering all the stations in eight urban areas in the U.S. while the majority of them are limited to one region or a few (Atkinson-Palombo and Kuby, 2011; Duncan, 2010; Hale, 2014; Jeihani et al., 2013; Kamruzzaman et al., 2015; Vale, 2015; Ngo, 2012; Pollack et al., 2014; Renne, 2009; Zamir et al., 2014). Renne and Ewing (2013) cover 54 
regions across the U.S., but this study utilizes a more objective and systematic analysis-the hierarchical cluster analysis.

Household characteristics and travel behaviors from household travel survey data were matched to each station area type, and this study found that residents living in different types of station area are different from each other. Households in TAD tend to be more affluent, have more cars, include more people, and be more auto-oriented than their counterparts in TOD. Regarding travel behavior, TAD households have far more VMT and fewer walk and transit trips than those in TODs and Hybrids. The average number of daily automobile trips shows the most dramatic differences; TAD households generate three times as many as TOD households (6.06 vs. 2.04). The big difference in mode share between TOD and TAD (e.g. auto mode shares in TAD and TOD are 68\% and 25\%, respectively) is observed in other studies (Renne, 2009; Renne and Ewing, 2013), sometimes less dramatically_approximately 70\% (TOD) vs. 85\% (non-TOD) (Kamruzzaman et al., 2013; Jeihani et al., 2013).

Because households in TADs are likely to differ in multiple ways from those in TOD or Hybrid areas, residential self-selection matters when we try to analyze the pure effect of the TOD built environment on travel behaviors. In this study, propensity score matching enables the researcher to match samples so as to control for residential self-selection.

Although the differences in travel outcomes become less dramatic after controlling for selfselection, the matched sample still shows that TOD motivates its residents to walk more and take transit more while using personal vehicles less. The significant difference between TOD and TAD in both VMT and the number of auto trips means that TOD makes the personal vehicle trips both shorter (39\% shorter VMT per household) and fewer (35\% fewer auto trips per household). By considering the in-between Hybrid type, this study could offer some practical policy suggestions. The result shows that frequencies of auto trips, transit trips, and walk trips are all slightly different between TAD and Hybrid, and only the frequencies of auto and walk trips are significantly different between TOD and Hybrid. Therefore, when a local government and transit authority develop a TAD-type station area which is sprawled, single-use, and not walkable into a Hybrid type mainly by adding different land uses, they could expect small increases in transit and walk trips. Then a Hybrid type of station area could be changed into a TOD type through infill or new developments adding density and/or decreasing block sizes (e.g. adding walking routes through existing blocks), which would result in less driving and more walking by their residents. Then the cumulative change from a TAD to a TOD could encourage its residents to drive shorter and less, walk more, and take transit more, which will have positive impacts on the city's environment, society, and economy.

Transit-oriented development is expected to promote sustainable travel behavior by reducing auto-dependency and increasing residents' use of transit and active transportation modes. This study demonstrates that TOD, a station area having a dense, mixed-use, walkable, and transitfriendly environment, could meet these expectations. One application of the study results could be an exploratory, preliminary analysis of the traffic impacts of a TOD project seen in Table 5-2. For example, when a suburban TAD is redeveloped to become a TOD, planners can expect 39\% decrease in daily VMT per household, 35\% decrease in daily automobile trips, 148\% increase in daily transit trips, and $110 \%$ increase in daily walk trips. Also, the significant savings in 
transportation spending in TOD neighborhoods, mainly generated from reduced vehicle use cost, is one social benefit of a dense, mixed-use, and walkable development in a station area, which supports a rationale for TOD.

This study has three main limitations. First, station area classification might generate different results if you change the input-e.g., if you include different regions or different builtenvironment factors. The result also depends on the clustering method utilized. The classification, because it relies on cluster analysis, cannot provide such guidance as benchmark thresholds of density, land use mix, or street connectivity (see Renne and Ewing, 2013; Renne et al., 2016). Nevertheless, the clustering approach in this study might reflect reality better than using hypothetical benchmarks. Also, the result shows that different station areas have meaningfully different effects on residents' travel.

Second, propensity score matching yields certainty only when all confounding factors are included in the analysis. This study, however, includes only the factors reflecting self-selection indirectly, which are household demographic characteristics-household size, employment, income, vehicle ownership — and location factors - distance to station, regional job accessibility - and does not include, for instance, information on residents' attitudes. The risk of not controlling for all confounding factors is that we might under- or overestimate the effect of residential self-selection on travel behavior. To our knowledge, there are no such attitude data covering multiple regions in the U.S., but this study needs to be checked for external validity by additional TOD studies including residential preference data in specific regions.

Third, in theory, the observed covariates in the propensity score equation are measured before the treatment while the outcome is measured after the treatment (Rosenbaum and Rubin, 1984. In the context of this study, the data point for household characteristics and location factors needs to be before the station area was developed, while the travel outcome data should be collected after the development. This requires longitudinal data. However, because the regional household travel surveys are conducted in different years in each region, it is not plausible to put all longitudinal data into one analysis. Also, even if the data analysis is available, the theoretical propensity score analysis does not fit into the reality of station area developments. Most neighborhoods around stations have been developed over time, meaning that there might be no such "treatment point.” Although this study uses cross-sectional data to control the temporal differences across regions and stations, further research needs more advanced methods.

Nevertheless, as a first-of-its-kind study using both cluster analysis and propensity score matching in TOD/TAD classification, this study provides an evidence that a TOD and even a Hybrid station area could encourage its residents to use more active modes of transportation. An effort to create a transit-oriented neighborhood does not have to be a "mega-project." Gradual changes of a station area into a denser, more diverse, and more walkable environment would compensate us in the form of sustainable travel behavior, which ultimately gives environmental, social, and economic benefits. 


\subsection{REFERENCES}

Agrawal, Asha Weinstein, Evelyn Blumenberg, Sarah Abel, Gregory Pierce and Charles N. Darrah. 2011. Getting Around When You're Just Getting By: The Travel Behavior and Transportation Expenditures of Low-Income Adults. Mineta Transportation Institute (CA-MTI10-2806), San José State University. Retrieved from http://trid.trb.org/view/2011/M/1097942 (Accessed Dec. 12, 2016)

Anderson, W. P., P. S. Kanaroglou and E. J. Miller. 1996. "Urban form, energy and the environment: A review of issues, evidence and policy.” Urban Studies, 33, 7-35.

Atkinson-Palombo, Carol, and Michael J. Kuby. 2011. "The Geography of Advance TransitOriented Development in Metropolitan Phoenix, Arizona, 2000-2007.” Journal of Transport Geography 19.2: 189-199.

Austin, Peter C. 2009. "Some Methods of Propensity-Score Matching Had Superior Performance to Others: Results of an Empirical Investigation and Monte Carlo Simulations.” Biometrical Journal 51.1: 171-184.

Bajic, V. (1983). “The effect of a new subway line on housing prices in metropolitan Toronto.” Urban Studies, 20, 147-158.

Belzer, D., and G. Autler. 2002. Transit Oriented Development: Moving from Rhetoric to Reality. Washington, DC: Brookings Institution Center on Urban and Metropolitan Policy.

Bernick, Michael, and Robert Cervero. 1997. Transit Villages in the 21st Century. New York: McGraw-Hill.

Boer, Rob, Yuhui Zheng, Adrian Overton, Gregory K. Ridgeway and Deborah A. Cohen. 2007. "Neighborhood Design and Walking Trips in Ten US Metropolitan Areas." American journal of preventive medicine 32.4: 298-304.

Brown, B.B., and C.M. Werner. 2011. “The Residents’ Benefits and Concerns Before and After a New Rail Stop: Do Residents Get What They Expect?” Environment and Behavior 43, 789806.

Burchell, R.W., N.A. Shad, D. Listokin, H. Phillips, A. Downs, S. Seskin, and M. Gall. 2000. “The Benefits of Sprawl.” TCRP Report 39: The Costs of Sprawl-Revisited. TRB, National Research Council, Washington, D.C., pp. 351-391.

Canepa, B. 2007. "Bursting the Bubble: Determining the Transit-Oriented Development's Walkable Limits.” Transportation Research Record: Journal of the Transportation Research Board (vol. 1992), 28-34. 
Cao, Xinyu Jason. 2010. "Exploring Causal Effects of Neighborhood Type on Walking Behavior Using Stratification on the Propensity Score.” Environment and Planning A 42.2: 487-504.

Cao, Xinyu Jason, and Yingling Fan. 2012. "Exploring the Influences of Density on Travel Behavior Using Propensity Score Matching." Environment and Planning B: Planning and Design 39.3: 459-470.

Cao, Xinyu Jason, Patricia L. Mokhtarian, and Susan L. Handy. 2009. "Examining the Impacts of Residential Self-Selection on Travel Behaviour: a focus on empirical findings." Transport Reviews 29.3: 359-395.

Cao, Xinyu Jason, and Jessica Schoner. 2014. "The influence of light rail transit on transit use: An exploration of station area residents along the Hiawatha line in Minneapolis." Transportation Research Part A: Policy and Practice 59: 134-143.

Cao, Xinyu Jason, Zhiyi Xu, and Yingling Fan. 2010. "Exploring the Connections Among Residential Location, Self-Selection, and Driving: Propensity Score Matching with Multiple Treatments.” Transportation research part A: policy and practice 44.10: 797-805.

Center for Transit-Oriented Development. 2010. Performance-Based Transit-Oriented Development Typology Guidebook.

Center for Transit-Oriented Development. 2011. "Planning for TOD at the Regional Scale: The Big Picture.” Report TOD 204.

Cervero, Robert, 1993. Ridership Impacts of Transit-Focused Development in California. Institute of Urban and Regional Development, University of California, Berkeley, CA (Monograph 45).

Cervero, Robert, 2004. "Transit-Oriented Development in the United States: Experiences, Challenges, and Prospects,” TCRP Report 102. Transportation Research Board.

Cervero, Robert, and G. B. Arrington. 2008. "Vehicle trip reduction impacts of transit-oriented housing.” Journal of Public Transportation 11(3): 1-17.

Cervero, Robert, and Michael Duncan. 2002. "Residential Self Selection and Rail Commuting: A Nested Logit Analysis.” Berkeley: UCTC Working Paper. Accessed 25 April 2013. Available at: http://www.uctc.net/papers/604.pdf

Cervero, Robert, and R. Gorham. 1995. "Commuting in transit versus automobile neighborhoods.” Journal of the American Planning Association 61, 210.

Cervero, Robert, and K. Kockelman. 1997. "Travel demand and the 3Ds: density, diversity, and design.” Transportation Research Part D: Transportation and Environment 2 (3), 199-219. 
Charrad, M., N. Ghazzali, V. Boiteau and A. Niknafs. 2014. "NbClust: An R Package for Determining the Relevant Number of Clusters in a Data Set.” Journal of Statistical Software, 61(6), 1-36.

Currie, G., \& Senbergs, Z. (2007). Exploring forced car ownership in metropolitan Melbourne. Australasian Transport Research Forum 2007.

Dawkins, C. J. 2009. "Urban Sprawl and the Transition to First-Time Homeownership.” Cityscape, Vol. 11, No. 2, pp. 83-100.

Dittmar, Hank, and Gloria Ohland. 2004. The new transit town: Best practices in transit oriented development. Washington, DC; London: Island Press.

Dodson, J., and N. Sipe. 2008. "Shocking the suburbs: Urban location, homeownership and oil vulnerability in the Australian city.” Housing Studies, 23, 377-401.

Duncan, M. 2010. "The impact of transit-oriented development on housing prices in San Diego, CA.” Urban studies, Vol. 48, Issue 1.

Ewing, R., S. Hamidi and J.B. Grace. 2016. "Compact development and VMT—Environmental determinism, self-selection, or some of both?” Environment and Planning B: Planning and Design, 43(4), pp.737-755.

Ewing, R., G. Tian, J. P. Goates, M. Zhang, M. J. Greenwald, A. Joyce, J. Kircher and W. Greene. 2015. "Varying influences of the built environment on household travel in 15 diverse regions of the United States.” Urban Studies, 52(13). 2330-2348.

Fan, Y. and A. Huang. 2011. How affordable is transportation? A context-sensitive framework. CTS 11-12. Center for Transportation Studies, University of Minnesota. Accessed Aug. 3, 2017, at http://www.cts.umn.edu/Publications/ResearchReports/reportdetail.html?id=2024.

Gibbons, S., and S. Machin. 2005. "Valuing rail access using transport innovations.” Journal of Urban Economics, 57, 148-169.

Glaeser, E., and J. Gyourko. 2003. “The impact of building restrictions on housing affordability.” Economic Policy Review, 9, 21-39.

Haas, P., C. Makarewicz, A. Benedict and S. Bernstein. 2008. "Estimating transportation costs by characteristics of neighborhood and household.” Transportation Research Record: Journal of the Transportation Research Board, (2077), 62-70.

Haas, P., S. Morse, S. Becker, L. Young and P. Esling. 2013. "The influence of spatial and household characteristics on household transportation costs.” Research in Transportation Business \& Management, 7, pp.14-26.

Halbur, T. 2007. “TOD’s Evil Twin: Transit-Adjacent Development.” Mass Transit Magazine Online. 
Hale, C. 2014. “TOD versus TAD: the great debate resolved...(?).” Planning Practice and Research, 29(5), 492-507.

Hamidi, S., Ewing, R. and Renne, J. 2016. "How Affordable Is HUD Affordable Housing?” Housing Policy Debate, 26(3), pp.437-455.

Handy, S., 2004. "Does the Built Environment Influence Physical Activity? Examining the Evidence. Critical Assessment of the Literature on the Relationships Among Transportation, Land Use and Physical Activity.” Transportation Research Board Special Report 2005, 282.

Hickey, R., Lubell, J., Haas, P., \& Morse, S. (2012). Losing ground: The struggle of moderateincome households to afford the rising costs of housing and transportation. Center for Housing Policy \& Center for Neighborhood Technology. Accessed Dec. 12, 2016, at http://www.cnt.org/sites/default/files/publications/CNT_LosingGround.pdf.

Horner, M. W. 2002. "Extensions to the concept of excess commuting." Environment and Planning A, 34, 543-566.

Jeihani, M., L. Zhang, A. Ardeshiri, A. Amiri, A. Nasri, K. R. Zamir and B. Baghaei. 2013. Development of a Framework for Transit-Oriented Development (TOD) (No. MD-13SP209B4N).

Jewkes, M. D., and L. M. Delgadillo. 2010. "Weaknesses of Housing Affordability Indices Used by Practitioners.” Journal of Financial Counseling and Planning, 21: (1) pg. 43-52.

Kamruzzaman, M., D. Baker, S. Washington and G. Turrell. 2013. "Residential dissonance and mode choice.” Journal of transport geography. 33 (December), 12-28.

Kamruzzaman, M., D. Baker, S. Washington and G. Turrell. 2014. “Advance transit oriented development typology: case study in Brisbane, Australia." Journal of Transport Geography, 34, 54-70.

Kamruzzaman, M., F. M. Shatu, J. Hine and G. Turrell. 2015. "Commuting mode choice in transit oriented development: Disentangling the effects of competitive neighbourhoods, travel attitudes, and self-selection.” Transport Policy, 42, 187-196.

Kellett, J., J. Morrissey and S. Karuppannan. 2012. The impact of location on housing affordability. In 6th Australasian housing researchers' conference. Adelaide: The University of Adelaide.

Laaly, S. 2014. New definition of transit oriented development (TOD) based on context sensitive paradigm (Order No. 3626280). Available from ProQuest Dissertations and Theses Global. (1551496943). Retrieved from http://search.proquest.com/docview/1551496943.

Langlois, M., D. van Lierop, R. A. Wasfi and A. M. El-Geneidy. 2015. “Chasing Sustainability: Do New Transit-Oriented Development Residents Adopt More Sustainable Modes of 
Transportation?” Transportation Research Record: Journal of the Transportation Research Board (2531), 83-92.

Lechner, Michael. "Program heterogeneity and propensity score matching: An application to the evaluation of active labor market policies.” Review of Economics and Statistics 84.2 (2002): 205220.

Lipman, B. J. (2006). A Heavy Load: The Combined Housing and Transportation Burdens of Working Families. Center for Housing Policy. Retrieved Dec. 12, 2016, from http://www.reconnectingamerica.org/assets/Uploads/pubheavyload1006.pdf.

Low, N., B. Gleeson, R. Green and D. Radović. 2005. The green city: Sustainable homes, sustainable suburbs. Sydney: University of New South Wales.

Mattingly, K., and J. Morrissey. 2014. "Housing and transport expenditure: Socio-spatial indicators of affordability in Auckland.” Cities 38: 69-83.

Mokhtarian, Patricia L., and Xinyu Cao. 2008. "Examining the impacts of residential selfselection on travel behavior: A focus on methodologies." Transportation Research Part B: Methodological 42.3: 204-228.

Nasri, A., and L. Zhang. 2014. "The analysis of transit-oriented development (TOD) in Washington, D.C., and Baltimore metropolitan areas.” Transport Policy 32 (1), 172-179.

Newman, P. W. G., and J. R. Kenworthy. 1989. "Gasoline consumption and cities: a comparison of U.S. cities with a global survey.” Journal of the American Planning Association, 55, pp. 2437.

Ngo, V. 2012. "Identifying Areas for Transit-Oriented Development in Vancouver.” Trail Six: An Undergraduate Journal of Geography 6.

Noland, R.B., K. Ozbay, S. Dipetrillo and S. Iyer. 2014. "Measuring Benefits of Transit Oriented Development." Mineta National Transit Research Consortium Report 12-18.

Oakes, J. M., and P. J. Johnson. 2006. "Propensity score matching for social epidemiology.” Methods in social epidemiology 1, 370-393.

Olaru, D. and C. Curtis. 2015. "Designing TOD precincts: accessibility and travel patterns.” Planning Practice and Research 15(1), 1567-7141.

Pollack, S., A. Gartsman, M. Boston, A. Benedict and J. Wood. 2014. "Rating the Performance of Station Areas for Effective and Equitable Transit-Oriented Development." in Transportation Research Board 93rd Annual Meeting (No. 14-0392).

Quigley, J. M., and S. Raphael. 2005. "Regulation and the high cost of housing in California." The American Economic Review, 323-328. 
Renne, J. 2005. Transit Oriented Development: Measuring Benefits, Analyzing Trends, and Evaluating Policy, Ph.D. Dissertation in Urban Planning and Policy Development. Rutgers University.

Renne, John. 2009. “From Transit-Adjacent to Transit-Oriented Development.” Local Environment, 14:1, p. 1-15.

Renne, John L. and Reid Ewing. 2013. Transit-Oriented Development: An Examination of America's Transit Precincts in 2000 and 2010. UNOTI Publications. Paper 17.

http://scholarworks.uno.edu/unoti_pubs/17

Renne, J.L., T. Tolford, S. Hamidi and R. Ewing. 2016. “The Cost and Affordability Paradox of Transit-Oriented Development: A Comparison of Housing and Transportation Costs Across Transit-Oriented Development, Hybrid and Transit-Adjacent Development Station Typologies.” Housing Policy Debate 26(4-5), pp.819-834.

Rice, L. 2004. Transportation spending by low-income California households: lessons for the San Francisco Bay Area. San Francisco: Public Policy Institute of California. Accessed Dec, 13, 2016, at http://www.ppic.org/content/pubs/report/R_704LRR.pdf.

Rosenbaum, P. R., and D. B. Rubin. 1984. "Reducing bias in observational studies using subclassification on the propensity score.” Journal of the American Statistical Association, 79(387), 516-524.

Sanchez, T., and M. Brenman. 2007. The Right to Transportation: Moving to Equity. APA Planners Press, Chicago, IL.

So, H. M., R. Y. C. Tse, and S. Ganesan. 1997. "Estimating the influence of transport on house prices: Evidence from Hong Kong.” Journal of Property Valuation and Investment, 15, 40-47.

Vale, D. S. 2015. “Transit-oriented development, integration of land use and transport, and pedestrian accessibility: Combining node-place model with pedestrian shed ratio to evaluate and classify station areas in Lisbon.” Journal of Transport Geography, 45, 70-80.

Venigalla, M., and A. Faghri. 2015. “A Quick-Response Discrete Transit-Share Model for Transit-Oriented Developments.” Journal of Public Transportation 18(3): 107-123.

Viggers, H., and P. Howden-Chapman. 2011. "Urban form, public transport and mortgagee sales.” In K. Witten, W. Abrahamse and K. Stuart (Eds.), Growth misconduct? Avoiding sprawl and improving urban intensification in New Zealand (pp. 159-177). Wellington: Steele Roberts Aotearoa.

Werner, C. M., B. B. Brown and J. Gallimore. 2010. “Light rail use is more likely on 'walkable' blocks: Further support for using micro-level environmental audit measures.” Journal of Environmental Psychology 30, 206-214.

U.S. Bureau of Labor Statistics. 2014. Consumer Expenditure Survey. 
Zamir, K.R., A. Nasri, B. Baghaei, S. Mahapatra and L. Zhang. 2014. "Comparative Analysis of the Effect of Transit-Oriented Development on Trip Generation, Distribution, and Mode Share in the Washington, D.C. and Baltimore Metropolitan Areas.” Transportation Research Board 2014 Annual Meeting: 1-19. 


\subsection{APPENDICES}

\subsection{APPENDIX A: LIST OF STATION AREAS BY TYPE}

Table 1. Station area types and their built-environment characteristics

\begin{tabular}{|c|c|c|c|c|c|c|c|}
\hline \multirow[t]{2}{*}{$\begin{array}{l}\text { Cluster } \\
\text { type }\end{array}$} & \multirow{2}{*}{$\begin{array}{l}\text { Number } \\
\text { of } \\
\text { Stations }\end{array}$} & \multicolumn{2}{|c|}{$\begin{array}{l}\text { Activity Density } \\
\text { (/sq.mi.) }\end{array}$} & \multicolumn{2}{|c|}{ Entropy Index } & \multicolumn{2}{|c|}{$\begin{array}{c}\text { Intersection Density } \\
\text { (/sq.mi.) }\end{array}$} \\
\hline & & Mean & S.D. & Mean & S.D. & Mean & S.D. \\
\hline TAD & 107 & 10,319 & 11,751 & 0.30 & 0.19 & 110 & 58 \\
\hline Hybrid & 382 & 21,210 & 19,764 & 0.75 & 0.15 & 194 & 79 \\
\hline TOD & 60 & 135,327 & 51,025 & 0.70 & 0.24 & 386 & 110 \\
\hline TOTAL & 549 & 31,559 & 43,821 & 0.66 & 0.24 & 199 & 108 \\
\hline
\end{tabular}

Table 2. List of Station Areas by Type (8 regions, 549 stations)

Station name

1 Arts Center Station

2 Avondale Station

3 Bankhead Station

4 Buckhead Station

5 Chamblee Station

6 Doraville Station

7 Dunwoody Station

8 East Lake Station

9 Indian Creek Station

10 Lenox Station

11 Lindbergh Center Station

12 Lindbergh Pocket

13 Medical Center Station

14 North Springs Station

15 Sandy Springs Station

16 Abington

17 Auburndale

18 Ballardvale

19 Beverly Farms

20 Bridgewater
Region

Atlanta

Atlanta

Atlanta

Atlanta

Atlanta

Atlanta

Atlanta

Atlanta

Atlanta

Atlanta

Atlanta

Atlanta

Atlanta

Atlanta

Atlanta

Boston

Boston

Boston

Boston

Boston
Transit Year Type open
Activity Land Intersect Area

Density Use ion Type (pop+job/ Entropy Density sq.mi.)

Heavy Pre-2000

Heavy

Pre-2000

Heavy

Pre-2000

Heavy

Pre-2000

Heavy

Pre-2000

Heavy

Pre-2000

Heavy

Pre-2000

Heavy

Pre-2000

Heavy

Pre-2000

Heavy

Pre-2000

Heavy

Pre-2000

Heavy

Pre-2000

Heavy

Pre-2000

Heavy

Pre-2000

Heavy

Pre-2000

Commuter Pre-2000

Commuter Pre-2000

Commuter Pre-2000

Commuter Pre-2000

Commuter Pre-2000

$\begin{array}{rlr}43848 & 0.50 & 126 \text { TAD } \\ 4495 & 0.15 & 135 \text { TAD } \\ 4151 & 0.43 & 127 \text { TAD } \\ 30958 & 0.40 & 83 \text { TAD } \\ 6624 & 0.35 & 72 \text { TAD } \\ 6173 & 0.21 & 143 \text { TAD } \\ 22811 & 0.00 & 90 \text { TAD } \\ 6282 & 0.37 & 122 \text { TAD } \\ 1846 & 0.00 & 0 \text { TAD } \\ 18016 & 0.59 & 81 \text { TAD } \\ 19984 & 0.51 & 111 \text { TAD } \\ 20108 & 0.51 & 109 \text { TAD } \\ 41794 & 0.46 & 86 \text { TAD } \\ 11488 & 0.60 & 20 \text { TAD } \\ 14555 & 0.18 & 155 \text { TAD } \\ 2222 & 0.48 & 82 \text { TAD } \\ 7868 & 0.26 & 240 \text { TAD } \\ 1831 & 0.42 & 67 \text { TAD } \\ 805 & 0.24 & 79 \text { TAD } \\ 6767 & 0.51 & 97 \text { TAD }\end{array}$




\begin{tabular}{|c|c|c|c|c|c|c|}
\hline 21 Concord & Boston & Commuter & Pre-2000 & 2411 & 0.47 & $120 \mathrm{TAD}$ \\
\hline 22 Dedham Corp Center & Boston & Commuter & Pre-2000 & 4365 & 0.03 & $115 \mathrm{TAD}$ \\
\hline 23 Endicott & Boston & Commuter & Pre-2000 & 4542 & 0.34 & $170 \mathrm{TAD}$ \\
\hline 24 Halifax & Boston & Commuter & Pre-2000 & 1045 & 0.29 & 66 TAD \\
\hline 25 Hastings & Boston & Commuter & Pre-2000 & 910 & 0.28 & $63 \mathrm{TAD}$ \\
\hline 26 Hersey & Boston & Commuter & Pre-2000 & 4074 & 0.20 & 203 TAD \\
\hline 27 Littleton / Rte 495 & Boston & Commuter & Pre-2000 & 917 & 0.41 & 11 TAD \\
\hline 28 Nantasket Junction & Boston & Commuter & 2007 & 1007 & 0.30 & $64 \mathrm{TAD}$ \\
\hline 29 North Billerica & Boston & Commuter & Pre-2000 & 2384 & 0.30 & $118 \mathrm{TAD}$ \\
\hline 30 North Scituate & Boston & Commuter & 2007 & 1695 & 0.45 & $60 \mathrm{TAD}$ \\
\hline 31 North Wilmington & Boston & Commuter & Pre-2000 & 2024 & 0.42 & 69 TAD \\
\hline 32 Plimptonville & Boston & Commuter & Pre-2000 & 2407 & 0.39 & $78 \mathrm{TAD}$ \\
\hline 33 Prides Crossing & Boston & Commuter & Pre-2000 & 1144 & 0.27 & $42 \mathrm{TAD}$ \\
\hline 34 Rowley & Boston & Commuter & Pre-2000 & 331 & 0.46 & $36 \mathrm{TAD}$ \\
\hline 35 Shirley & Boston & Commuter & Pre-2000 & 871 & 0.59 & $98 \mathrm{TAD}$ \\
\hline 36 Silver Hill & Boston & Commuter & Pre-2000 & 830 & 0.09 & $56 \mathrm{TAD}$ \\
\hline 37 Wellesley Farms & Boston & Commuter & Pre-2000 & 4428 & 0.49 & 116 TAD \\
\hline 38 West Gloucester & Boston & Commuter & Pre-2000 & 714 & 0.13 & $51 \mathrm{TAD}$ \\
\hline 39 West Natick & Boston & Commuter & Pre-2000 & 6406 & 0.60 & $95 \mathrm{TAD}$ \\
\hline 40 Windsor Gardens & Boston & Commuter & Pre-2000 & 6973 & 0.44 & $140 \mathrm{TAD}$ \\
\hline 41 Airport Station & Boston & Heavy & Pre-2000 & 15982 & 0.42 & $172 \mathrm{TAD}$ \\
\hline $\begin{array}{l}42 \text { Wonderland Station-Blue } \\
\text { Line }\end{array}$ & Boston & Heavy & Pre-2000 & 8429 & 0.63 & 65 TAD \\
\hline 43 Beaconsfield Station & Boston & Light & Pre-2000 & 14891 & 0.40 & 198 TAD \\
\hline 44 Capen St & Boston & Light & Pre-2000 & 5670 & 0.12 & $156 \mathrm{TAD}$ \\
\hline 45 Central Ave & Boston & Light & Pre-2000 & 5165 & 0.47 & $122 \mathrm{TAD}$ \\
\hline 46 Newton Centre Station & Boston & Light & Pre-2000 & 9674 & 0.23 & $185 \mathrm{TAD}$ \\
\hline 47 Riverside Station & Boston & Light & Pre-2000 & 9152 & 0.50 & $111 \mathrm{TAD}$ \\
\hline 48 Valley Rd & Boston & Light & Pre-2000 & 5453 & 0.19 & $123 \mathrm{TAD}$ \\
\hline $\begin{array}{l}49 \text { Arapahoe at Village Center } \\
\text { Station }\end{array}$ & Denver & Light & 2006 & 12144 & 0.57 & $116 \mathrm{TAD}$ \\
\hline 50 Belleview Station & Denver & Light & 2006 & 22580 & 0.41 & 69 TAD \\
\hline 51 County Line Station & Denver & Light & 2006 & 11024 & 0.00 & 92 TAD \\
\hline 52 Dayton Station & Denver & Light & 2006 & 11355 & 0.00 & $82 \mathrm{TAD}$ \\
\hline 53 Lincoln Station & Denver & Light & 2006 & 8320 & 0.00 & $51 \mathrm{TAD}$ \\
\hline 54 Littleton / Mineral Ave Station & Denver & Light & Pre-2000 & 3833 & 0.47 & $72 \mathrm{TAD}$ \\
\hline 55 Louisiana Station & Denver & Light & 2006 & 8865 & 0.25 & $174 \mathrm{TAD}$ \\
\hline 56 Nine Mile Station & Denver & Light & 2006 & 1234 & 0.00 & $30 \mathrm{TAD}$ \\
\hline 57 Orchard Station & Denver & Light & 2006 & 19252 & 0.24 & $166 \mathrm{TAD}$ \\
\hline 58 Southmoor Station & Denver & Light & 2006 & 4892 & 0.24 & $126 \mathrm{TAD}$ \\
\hline 59 University of Denver Station & Denver & Light & 2006 & 6467 & 0.08 & $159 \mathrm{TAD}$ \\
\hline 60 Yale Station & Denver & Light & 2006 & 7534 & 0.16 & $159 \mathrm{TAD}$ \\
\hline
\end{tabular}




\begin{tabular}{|c|c|c|c|c|c|c|}
\hline 61 Palmetto Station Rail & Miami & Heavy & 2003 & 5215 & 0.61 & $48 \mathrm{TAD}$ \\
\hline 62 Coon Rapids Riverdale & Minneapolis & Commuter & 2009 & 3971 & 0.41 & $68 \mathrm{TAD}$ \\
\hline 63 Fridley Station & Minneapolis & Commuter & 2009 & 4123 & 0.41 & $168 \mathrm{TAD}$ \\
\hline 64 Target Field Station & Minneapolis & Commuter & 2009 & 49971 & 0.24 & 177 TAD \\
\hline 6528 Av Station & Minneapolis & Light & 2004 & 14038 & 0.00 & $128 \mathrm{TAD}$ \\
\hline 6638 St Station & Minneapolis & Light & 2004 & 8738 & 0.42 & $141 \mathrm{TAD}$ \\
\hline 6750 St Minnehaha Sta & Minneapolis & Light & 2004 & 6534 & 0.09 & $206 \mathrm{TAD}$ \\
\hline 68 American Blv 34 Av Station & Minneapolis & Light & 2004 & 8496 & 0.24 & 76 TAD \\
\hline 69 Bloomington Central Station & Minneapolis & Light & 2004 & 11252 & 0.23 & 77 TAD \\
\hline 70 Cedar-Riverside Station & Minneapolis & Light & 2004 & 22704 & 0.53 & $98 \mathrm{TAD}$ \\
\hline 71 Franklin Station & Minneapolis & Light & 2004 & 17338 & 0.24 & $188 \mathrm{TAD}$ \\
\hline 72 Humphrey Station & Minneapolis & Light & 2004 & 1048 & 0.00 & 50 TAD \\
\hline 73 Metrodome Station & Minneapolis & Light & 2004 & 72179 & 0.17 & $186 \mathrm{TAD}$ \\
\hline 74 Moa Transit Station & Minneapolis & Light & 2004 & 14738 & 0.00 & $179 \mathrm{TAD}$ \\
\hline 75 Va Medical Ctr Sta & Minneapolis & Light & 2004 & 2240 & 0.07 & $122 \mathrm{TAD}$ \\
\hline 76 Hall/Nimbus Wes Station & Portland & Commuter & 2009 & 10435 & 0.56 & $58 \mathrm{TAD}$ \\
\hline 77 Oregon City & Portland & Commuter & Pre-2000 & 1851 & 0.33 & $110 \mathrm{TAD}$ \\
\hline 78 Wilsonville Wes Station & Portland & Commuter & 2009 & 3584 & 0.37 & $38 \mathrm{TAD}$ \\
\hline 79 Albina/Mississippi Max Station & Portland & Light & 2004 & 8399 & 0.31 & $185 \mathrm{TAD}$ \\
\hline 80 Cascades Max Station & Portland & Light & 2001 & 3672 & 0.00 & 66 TAD \\
\hline $\begin{array}{l}81 \text { Clackamas Town Center TC } \\
\text { Max Station }\end{array}$ & Portland & Light & 2009 & 14795 & 0.15 & 23 TAD \\
\hline 82 Convention Center Max Station & Portland & Light & Pre-2000 & 33815 & 0.29 & $246 \mathrm{TAD}$ \\
\hline $\begin{array}{l}83 \text { Delta Park/Vanport Max } \\
\text { Station }\end{array}$ & Portland & Light & 2004 & 952 & 0.00 & $38 \mathrm{TAD}$ \\
\hline 84 E 148th Ave Max Station & Portland & Light & Pre-2000 & 6689 & 0.41 & 109 TAD \\
\hline 85 E 162nd Ave Max Station & Portland & Light & Pre-2000 & 10401 & 0.45 & 120 TAD \\
\hline 86 Expo Center Max Station & Portland & Light & 2004 & 124 & 0.00 & 25 TAD \\
\hline $\begin{array}{l}87 \text { Fair Complex/Hillsboro Airport } \\
\text { Max Stn }\end{array}$ & Portland & Light & Pre-2000 & 476 & 0.50 & 17 TAD \\
\hline $\begin{array}{l}88 \text { Interstate/Rose Quarter Max } \\
\text { Station }\end{array}$ & Portland & Light & 2004 & 27766 & 0.32 & $228 \mathrm{TAD}$ \\
\hline 89 Mt Hood Ave Max Station & Portland & Light & 2001 & 4242 & 0.00 & $72 \mathrm{TAD}$ \\
\hline 90 NE 7th Ave Max Station & Portland & Light & Pre-2000 & 39558 & 0.34 & 239 TAD \\
\hline $\begin{array}{l}91 \text { Portland Int’l Airport Max } \\
\text { Station }\end{array}$ & Portland & Light & 2001 & 2655 & 0.00 & $103 \mathrm{TAD}$ \\
\hline 92 Rose Quarter TC Max Station & Portland & Light & Pre-2000 & 29327 & 0.30 & $236 \mathrm{TAD}$ \\
\hline 93 SE Flavel St Max Station & Portland & Light & 2009 & 4778 & 0.54 & $84 \mathrm{TAD}$ \\
\hline 94 SE Fuller Rd Max Station & Portland & Light & 2009 & 5977 & 0.62 & $87 \mathrm{TAD}$ \\
\hline 95 SE Holgate Blvd Max Station & Portland & Light & 2009 & 5128 & 0.44 & $160 \mathrm{TAD}$ \\
\hline 96 Sunset TC Max Station & Portland & Light & Pre-2000 & 8133 & 0.46 & $70 \mathrm{TAD}$ \\
\hline 97 Washington Park Max Station & Portland & Light & Pre-2000 & 1839 & 0.34 & 67 TAD \\
\hline 982700 West & SaltLakeCity & Light & 2011 & 5967 & 0.57 & $104 \mathrm{TAD}$ \\
\hline
\end{tabular}




\begin{tabular}{|c|c|c|c|c|c|c|}
\hline 994800 West & SaltLakeCity & Light & 2011 & 5752 & 0.42 & $144 \mathrm{TAD}$ \\
\hline 100 Fort Douglas & SaltLakeCity & Light & 2003 & 23650 & 0.00 & $126 \mathrm{TAD}$ \\
\hline 101 Murray North Station & SaltLakeCity & Light & Pre-2000 & 1538 & 0.30 & $0 \mathrm{TAD}$ \\
\hline 102 University Medical Center & SaltLakeCity & Light & 2003 & 17644 & 0.15 & $125 \mathrm{TAD}$ \\
\hline 103 University South Campus & SaltLakeCity & Light & 2003 & 27173 & 0.00 & $137 \mathrm{TAD}$ \\
\hline 104 Tukwila Station & Seattle & Commuter & 2001 & 7523 & 0.07 & $74 \mathrm{TAD}$ \\
\hline 105 Beacon Hill & Seattle & Light & 2009 & 12066 & 0.27 & $287 \mathrm{TAD}$ \\
\hline 106 Seatac/Airport & Seattle & Light & 2009 & 7965 & 0.09 & 119 TAD \\
\hline 107 Sodo & Seattle & Light & 2009 & 13662 & 0.41 & $111 \mathrm{TAD}$ \\
\hline 108 Ashby Station & Atlanta & Heavy & Pre-2000 & 7199 & 0.53 & 211 Hybrid \\
\hline 109 Brookhaven-Oglethorpe Station & Atlanta & Heavy & Pre-2000 & 4731 & 0.65 & 143 Hybrid \\
\hline 110 Civic Center Station & Atlanta & Heavy & Pre-2000 & 60319 & 0.52 & 156 Hybrid \\
\hline 111 College Park Station & Atlanta & Heavy & Pre-2000 & 3474 & 0.61 & 148 Hybrid \\
\hline 112 Decatur Station & Atlanta & Heavy & Pre-2000 & 12207 & 0.96 & 160 Hybrid \\
\hline $\begin{array}{l}113 \text { Dome-Gwcc-Philips Arena- } \\
\text { Cnn Station }\end{array}$ & Atlanta & Heavy & Pre-2000 & 38495 & 0.54 & 195 Hybrid \\
\hline 114 East Point Station & Atlanta & Heavy & Pre-2000 & 5322 & 0.50 & 176 Hybrid \\
\hline $\begin{array}{l}115 \text { Edgewood-Candler Park } \\
\text { Station }\end{array}$ & Atlanta & Heavy & Pre-2000 & 8986 & 0.60 & 144 Hybrid \\
\hline 116 Garnett Station & Atlanta & Heavy & Pre-2000 & 70657 & 0.60 & 204 Hybrid \\
\hline 117 Georgia State Station & Atlanta & Heavy & Pre-2000 & 51836 & 0.70 & 144 Hybrid \\
\hline 118 Hamilton E Holmes Station & Atlanta & Heavy & Pre-2000 & 4147 & 0.72 & 89 Hybrid \\
\hline $\begin{array}{l}119 \text { Inman Park-Reynoldstown } \\
\text { Station }\end{array}$ & Atlanta & Heavy & Pre-2000 & 7413 & 0.61 & 172 Hybrid \\
\hline 120 Kensington Station & Atlanta & Heavy & Pre-2000 & 5577 & 0.95 & 67 Hybrid \\
\hline 121 King Memorial Station & Atlanta & Heavy & Pre-2000 & 16176 & 0.80 & 182 Hybrid \\
\hline $\begin{array}{l}122 \text { Lakewood-Ft McPherson } \\
\text { Station }\end{array}$ & Atlanta & Heavy & Pre-2000 & 4593 & 0.88 & 105 Hybrid \\
\hline 123 Midtown Station & Atlanta & Heavy & Pre-2000 & 36658 & 0.79 & 162 Hybrid \\
\hline 124 North Avenue Station & Atlanta & Heavy & Pre-2000 & 44952 & 0.82 & 137 Hybrid \\
\hline 125 Oakland City Station & Atlanta & Heavy & Pre-2000 & 5545 & 0.62 & 145 Hybrid \\
\hline 126 Vine City Station & Atlanta & Heavy & Pre-2000 & 8541 & 0.94 & 247 Hybrid \\
\hline 127 West End Station & Atlanta & Heavy & Pre-2000 & 6310 & 0.53 & 135 Hybrid \\
\hline 128 West Lake Station & Atlanta & Heavy & Pre-2000 & 3927 & 0.78 & 116 Hybrid \\
\hline 129 Anderson/ Woburn & Boston & Commuter & 2011 & 3107 & 0.89 & 24 Hybrid \\
\hline 130 Andover & Boston & Commuter & Pre-2000 & 7181 & 0.95 & 132 Hybrid \\
\hline 131 Ashland & Boston & Commuter & Pre-2000 & 1005 & 0.86 & 39 Hybrid \\
\hline 132 Ayer & Boston & Commuter & Pre-2000 & 2152 & 0.88 & 155 Hybrid \\
\hline 133 Bellevue & Boston & Commuter & Pre-2000 & 12229 & 0.65 & 245 Hybrid \\
\hline 134 Belmont & Boston & Commuter & Pre-2000 & 7045 & 0.60 & 198 Hybrid \\
\hline 135 Beverly & Boston & Commuter & Pre-2000 & 15918 & 0.75 & 326 Hybrid \\
\hline 136 Bradford & Boston & Commuter & Pre-2000 & 10401 & 0.56 & 182 Hybrid \\
\hline 137 Braintree & Boston & Commuter & Pre-2000 & 4298 & 1.00 & 104 Hybrid \\
\hline
\end{tabular}




\begin{tabular}{|c|c|c|c|c|c|c|}
\hline 138 Brandeis/ Roberts & Boston & Commuter & Pre-2000 & 10727 & 0.88 & 94 Hybrid \\
\hline 139 Brockton & Boston & Commuter & Pre-2000 & 14893 & 0.99 & 229 Hybrid \\
\hline 140 Campello & Boston & Commuter & Pre-2000 & 9543 & 0.92 & 159 Hybrid \\
\hline 141 Canton Center & Boston & Commuter & Pre-2000 & 6975 & 0.75 & 154 Hybrid \\
\hline 142 Canton Junction & Boston & Commuter & Pre-2000 & 3231 & 0.66 & 124 Hybrid \\
\hline 143 Chelsea & Boston & Commuter & Pre-2000 & 38067 & 0.92 & 262 Hybrid \\
\hline 144 Cohasset & Boston & Commuter & 2007 & 732 & 0.86 & 37 Hybrid \\
\hline 145 East Weymouth & Boston & Commuter & 2007 & 4586 & 0.60 & 131 Hybrid \\
\hline 146 Fairmount & Boston & Commuter & Pre-2000 & 11962 & 0.78 & 223 Hybrid \\
\hline 147 Forest Hills & Boston & Commuter & Pre-2000 & 13060 & 0.81 & 218 Hybrid \\
\hline 148 Forge Park/495 & Boston & Commuter & Pre-2000 & 2538 & 0.94 & 64 Hybrid \\
\hline 149 Framingham & Boston & Commuter & Pre-2000 & 15266 & 0.99 & 214 Hybrid \\
\hline 150 Franklin & Boston & Commuter & Pre-2000 & 6195 & 0.85 & 131 Hybrid \\
\hline 151 Gloucester & Boston & Commuter & Pre-2000 & 14849 & 0.83 & 345 Hybrid \\
\hline 152 Greenbush & Boston & Commuter & 2007 & 1246 & 0.90 & 105 Hybrid \\
\hline 153 Greenwood & Boston & Commuter & Pre-2000 & 4626 & 0.57 & 162 Hybrid \\
\hline 154 Hamilton/Wenham & Boston & Commuter & Pre-2000 & 1072 & 0.75 & 112 Hybrid \\
\hline 155 Hanson & Boston & Commuter & Pre-2000 & 474 & 0.84 & 35 Hybrid \\
\hline 156 Haverhill & Boston & Commuter & Pre-2000 & 17860 & 0.89 & 296 Hybrid \\
\hline 157 Highland & Boston & Commuter & Pre-2000 & 10724 & 0.68 & 246 Hybrid \\
\hline 158 Holbrook/Randolph & Boston & Commuter & Pre-2000 & 3303 & 0.71 & 113 Hybrid \\
\hline 159 Hyde Park & Boston & Commuter & Pre-2000 & 12302 & 0.89 & 273 Hybrid \\
\hline 160 Ipswich & Boston & Commuter & Pre-2000 & 6592 & 0.73 & 200 Hybrid \\
\hline 161 Islington & Boston & Commuter & Pre-2000 & 6980 & 0.76 & 147 Hybrid \\
\hline 162 JFK/UMass & Boston & Commuter & Pre-2000 & 21077 & 0.89 & 236 Hybrid \\
\hline 163 Kendal Green & Boston & Commuter & Pre-2000 & 1023 & 0.70 & 48 Hybrid \\
\hline 164 Kingston & Boston & Commuter & Pre-2000 & 1443 & 0.91 & 15 Hybrid \\
\hline 165 Lawrence & Boston & Commuter & Pre-2000 & 15055 & 0.91 & 107 Hybrid \\
\hline 166 Lowell & Boston & Commuter & Pre-2000 & 19373 & 0.98 & 287 Hybrid \\
\hline 167 Lynn & Boston & Commuter & Pre-2000 & 25647 & 0.97 & 248 Hybrid \\
\hline 168 Malden Center & Boston & Commuter & Pre-2000 & 24297 & 0.89 & 303 Hybrid \\
\hline 169 Manchester & Boston & Commuter & Pre-2000 & 930 & 0.59 & 137 Hybrid \\
\hline 170 Melrose Cedar Park & Boston & Commuter & Pre-2000 & 12259 & 0.67 & 214 Hybrid \\
\hline 171 Melrose Highlands & Boston & Commuter & Pre-2000 & 8991 & 0.51 & 230 Hybrid \\
\hline 172 Middleboro/Lakeville & Boston & Commuter & Pre-2000 & 616 & 0.98 & 68 Hybrid \\
\hline 173 Mishawum & Boston & Commuter & Pre-2000 & 10275 & 0.67 & 96 Hybrid \\
\hline 174 Montello & Boston & Commuter & Pre-2000 & 8015 & 0.68 & 185 Hybrid \\
\hline 175 Montserrat & Boston & Commuter & Pre-2000 & 8439 & 0.57 & 153 Hybrid \\
\hline 176 Morton Street & Boston & Commuter & Pre-2000 & 19577 & 0.68 & 263 Hybrid \\
\hline 177 Natick & Boston & Commuter & Pre-2000 & 6788 & 0.64 & 274 Hybrid \\
\hline 178 Needham Center & Boston & Commuter & Pre-2000 & 8019 & 0.67 & 212 Hybrid \\
\hline 179 Needham Heights & Boston & Commuter & Pre-2000 & 7190 & 0.67 & 156 Hybrid \\
\hline
\end{tabular}




\begin{tabular}{|c|c|c|c|c|c|c|}
\hline 180 Needham Junction & Boston & Commuter & Pre-2000 & 6719 & 0.61 & 147 Hybrid \\
\hline 181 Newburyport & Boston & Commuter & Pre-2000 & 2652 & 1.00 & 79 Hybrid \\
\hline 182 Newtonville & Boston & Commuter & Pre-2000 & 9984 & 0.57 & 235 Hybrid \\
\hline 183 Norfolk & Boston & Commuter & Pre-2000 & 1920 & 0.70 & 52 Hybrid \\
\hline 184 North Beverly & Boston & Commuter & Pre-2000 & 4791 & 0.74 & 146 Hybrid \\
\hline 185 Norwood Central & Boston & Commuter & Pre-2000 & 13121 & 0.90 & 208 Hybrid \\
\hline 186 Norwood Depot & Boston & Commuter & Pre-2000 & 9878 & 0.79 & 182 Hybrid \\
\hline 187 Plymouth & Boston & Commuter & Pre-2000 & 3325 & 0.75 & 98 Hybrid \\
\hline 188 Porter Square & Boston & Commuter & Pre-2000 & 29316 & 0.48 & 401 Hybrid \\
\hline 189 Quincy Center & Boston & Commuter & Pre-2000 & 23964 & 0.97 & 223 Hybrid \\
\hline 190 Reading & Boston & Commuter & Pre-2000 & 7603 & 0.66 & 218 Hybrid \\
\hline 191 Readville & Boston & Commuter & Pre-2000 & 5749 & 0.89 & 165 Hybrid \\
\hline 192 River Works & Boston & Commuter & Pre-2000 & 15898 & 0.85 & 125 Hybrid \\
\hline 193 Rockport & Boston & Commuter & Pre-2000 & 3054 & 0.73 & 198 Hybrid \\
\hline 194 Roslindale Village & Boston & Commuter & Pre-2000 & 14567 & 0.68 & 253 Hybrid \\
\hline 195 Route 128 & Boston & Commuter & Pre-2000 & 2660 & 0.73 & 24 Hybrid \\
\hline 196 Ruggles & Boston & Commuter & Pre-2000 & 60084 & 0.36 & 305 Hybrid \\
\hline 197 Salem & Boston & Commuter & Pre-2000 & 16693 & 0.86 & 302 Hybrid \\
\hline 198 Sharon & Boston & Commuter & Pre-2000 & 2063 & 0.53 & 137 Hybrid \\
\hline 199 South Acton & Boston & Commuter & Pre-2000 & 1498 & 0.72 & 64 Hybrid \\
\hline 200 South Weymouth & Boston & Commuter & Pre-2000 & 1345 & 0.81 & 50 Hybrid \\
\hline 201 Stoughton & Boston & Commuter & Pre-2000 & 6545 & 0.80 & 209 Hybrid \\
\hline 202 Swampscott & Boston & Commuter & Pre-2000 & 10049 & 0.61 & 294 Hybrid \\
\hline 203 Uphams Corner & Boston & Commuter & Pre-2000 & 25846 & 0.83 & 405 Hybrid \\
\hline 204 Wakefield & Boston & Commuter & Pre-2000 & 8541 & 0.89 & 187 Hybrid \\
\hline 205 Walpole & Boston & Commuter & Pre-2000 & 1892 & 0.67 & 137 Hybrid \\
\hline 206 Waltham & Boston & Commuter & Pre-2000 & 20089 & 0.97 & 266 Hybrid \\
\hline 207 Waverley & Boston & Commuter & Pre-2000 & 10951 & 0.78 & 215 Hybrid \\
\hline 208 Wedgemere & Boston & Commuter & Pre-2000 & 4433 & 0.42 & 211 Hybrid \\
\hline 209 Wellesley Hills & Boston & Commuter & Pre-2000 & 6235 & 0.73 & 150 Hybrid \\
\hline 210 Wellesley Square & Boston & Commuter & Pre-2000 & 7281 & 0.88 & 144 Hybrid \\
\hline 211 West Concord & Boston & Commuter & Pre-2000 & 3844 & 0.77 & 133 Hybrid \\
\hline 212 West Hingham & Boston & Commuter & 2007 & 2331 & 0.85 & 55 Hybrid \\
\hline 213 West Medford & Boston & Commuter & Pre-2000 & 8722 & 0.45 & 266 Hybrid \\
\hline 214 West Newton & Boston & Commuter & Pre-2000 & 8591 & 0.40 & 241 Hybrid \\
\hline 215 West Roxbury & Boston & Commuter & Pre-2000 & 8769 & 0.73 & 221 Hybrid \\
\hline $\begin{array}{l}216 \text { Weymouth Landing/East } \\
\text { Braintree }\end{array}$ & Boston & Commuter & 2007 & 6100 & 0.75 & 172 Hybrid \\
\hline 217 Whitman & Boston & Commuter & Pre-2000 & 2590 & 0.56 & 128 Hybrid \\
\hline 218 Wilmington & Boston & Commuter & Pre-2000 & 2716 & 0.85 & 89 Hybrid \\
\hline 219 Winchester Center & Boston & Commuter & Pre-2000 & 7851 & 0.81 & 240 Hybrid \\
\hline 220 Wyoming Hill & Boston & Commuter & Pre-2000 & 8231 & 0.45 & 273 Hybrid \\
\hline
\end{tabular}




\begin{tabular}{|c|c|c|c|c|c|c|}
\hline 221 Yawkey & Boston & Commuter & Pre-2000 & 60896 & 0.90 & 218 Hybrid \\
\hline 222 Alewife Station Red Line & Boston & Heavy & Pre-2000 & 16673 & 0.92 & 67 Hybrid \\
\hline 223 Andrew Sq Station & Boston & Heavy & Pre-2000 & 19239 & 0.89 & 328 Hybrid \\
\hline 224 Beachmont Station & Boston & Heavy & Pre-2000 & 11374 & 0.89 & 243 Hybrid \\
\hline $\begin{array}{l}225 \text { Braintree Station Red Line } \\
\text { Platform }\end{array}$ & Boston & Heavy & Pre-2000 & 4107 & 1.00 & 107 Hybrid \\
\hline 226 Broadway Station & Boston & Heavy & Pre-2000 & 24843 & 0.73 & 282 Hybrid \\
\hline 227 Central Sq & Boston & Heavy & Pre-2000 & 49276 & 0.75 & 464 Hybrid \\
\hline 228 Community College & Boston & Heavy & Pre-2000 & 25957 & 0.79 & 284 Hybrid \\
\hline 229 Davis Sq & Boston & Heavy & Pre-2000 & 32443 & 0.59 & 408 Hybrid \\
\hline 230 Fields Corner Station & Boston & Heavy & Pre-2000 & 28562 & 0.81 & 314 Hybrid \\
\hline 231 Forest Hills Orange Line & Boston & Heavy & Pre-2000 & 13183 & 0.81 & 225 Hybrid \\
\hline 232 Harvard Station & Boston & Heavy & Pre-2000 & 62875 & 0.84 & 283 Hybrid \\
\hline 233 Jackson Sq & Boston & Heavy & Pre-2000 & 27511 & 0.81 & 342 Hybrid \\
\hline $\begin{array}{l}234 \text { JFK/UMass Ashmont Line } \\
\text { Inbound }\end{array}$ & Boston & Heavy & Pre-2000 & 21040 & 0.89 & 213 Hybrid \\
\hline 235 Kendall/MIT Station & Boston & Heavy & Pre-2000 & 51253 & 0.74 & 191 Hybrid \\
\hline 236 Malden Station & Boston & Heavy & Pre-2000 & 24866 & 0.96 & 299 Hybrid \\
\hline 237 Maverick Station & Boston & Heavy & Pre-2000 & 32814 & 0.90 & 343 Hybrid \\
\hline 238 North Quincy Station & Boston & Heavy & Pre-2000 & 13102 & 0.92 & 186 Hybrid \\
\hline $\begin{array}{l}239 \text { Oak Grove Station-Orange } \\
\text { Line }\end{array}$ & Boston & Heavy & Pre-2000 & 14129 & 0.55 & 276 Hybrid \\
\hline 240 Orient Heights Station & Boston & Heavy & Pre-2000 & 11838 & 0.85 & 213 Hybrid \\
\hline 241 Porter Sq & Boston & Heavy & Pre-2000 & 29254 & 0.48 & 401 Hybrid \\
\hline 242 Quincy Adams Station & Boston & Heavy & Pre-2000 & 10795 & 0.99 & 148 Hybrid \\
\hline 243 Quincy Center Station & Boston & Heavy & Pre-2000 & 24155 & 0.94 & 256 Hybrid \\
\hline 244 Revere Beach Station & Boston & Heavy & Pre-2000 & 17468 & 0.95 & 228 Hybrid \\
\hline 245 Roxbury Xng & Boston & Heavy & Pre-2000 & 37161 & 0.68 & 311 Hybrid \\
\hline 246 Ruggles Station & Boston & Heavy & Pre-2000 & 63505 & 0.51 & 328 Hybrid \\
\hline 247 Savin Hill Station & Boston & Heavy & Pre-2000 & 17093 & 0.86 & 220 Hybrid \\
\hline 248 Shawmut Station & Boston & Heavy & Pre-2000 & 25559 & 0.56 & 311 Hybrid \\
\hline 249 Stoneybrook & Boston & Heavy & Pre-2000 & 25654 & 0.71 & 387 Hybrid \\
\hline 250 Suffolk Downs Station & Boston & Heavy & Pre-2000 & 10053 & 0.79 & 120 Hybrid \\
\hline 251 Sullivan Station & Boston & Heavy & Pre-2000 & 17734 & 1.00 & 328 Hybrid \\
\hline 252 Wellington Station & Boston & Heavy & Pre-2000 & 11778 & 1.00 & 83 Hybrid \\
\hline 253 Wollaston Station & Boston & Heavy & Pre-2000 & 14055 & 0.66 & 277 Hybrid \\
\hline 254 Wood Island Station & Boston & Heavy & Pre-2000 & 16911 & 0.84 & 229 Hybrid \\
\hline 255 Allston St & Boston & Light & Pre-2000 & 42418 & 0.77 & 303 Hybrid \\
\hline 256 Ashmont Station & Boston & Light & Pre-2000 & 21804 & 0.57 & 285 Hybrid \\
\hline 257 Babcock St & Boston & Light & Pre-2000 & 47825 & 0.87 & 254 Hybrid \\
\hline 258 Back of Hill & Boston & Light & Pre-2000 & 36403 & 0.78 & 267 Hybrid \\
\hline 259 Blandford St & Boston & Light & Pre-2000 & 68490 & 0.84 & 268 Hybrid \\
\hline 260 Boston College Station & Boston & Light & Pre-2000 & 16987 & 0.78 & 108 Hybrid \\
\hline
\end{tabular}




\begin{tabular}{|c|c|c|c|c|c|c|}
\hline 261 Boston Univ Central & Boston & Light & Pre-2000 & 46716 & 0.92 & 253 Hybrid \\
\hline 262 Boston Univ East & Boston & Light & Pre-2000 & 59962 & 0.88 & 306 Hybrid \\
\hline 263 Boston Univ West & Boston & Light & Pre-2000 & 39045 & 0.92 & 223 Hybrid \\
\hline 264 Brandon Hall & Boston & Light & Pre-2000 & 32192 & 0.57 & 244 Hybrid \\
\hline 265 Brookline Hills Station & Boston & Light & Pre-2000 & 19085 & 0.64 & 270 Hybrid \\
\hline 266 Brookline Village Station & Boston & Light & Pre-2000 & 29978 & 0.86 & 310 Hybrid \\
\hline 267 Butler Station & Boston & Light & Pre-2000 & 11244 & 0.90 & 127 Hybrid \\
\hline 268 Cedar Grove & Boston & Light & Pre-2000 & 10433 & 0.74 & 215 Hybrid \\
\hline 269 Chestnut Hill Ave & Boston & Light & Pre-2000 & 26288 & 0.71 & 258 Hybrid \\
\hline 270 Chestnut Hill Station & Boston & Light & Pre-2000 & 3779 & 0.70 & 122 Hybrid \\
\hline 271 Chiswick Rd & Boston & Light & Pre-2000 & 32937 & 0.57 & 300 Hybrid \\
\hline 272 Cleveland Circle Platform & Boston & Light & Pre-2000 & 20786 & 0.67 & 226 Hybrid \\
\hline 273 Coolidge Corner & Boston & Light & Pre-2000 & 36074 & 0.68 & 245 Hybrid \\
\hline 274 Dean Rd & Boston & Light & Pre-2000 & 23285 & 0.52 & 249 Hybrid \\
\hline 275 Eliot Station & Boston & Light & Pre-2000 & 6232 & 0.42 & 215 Hybrid \\
\hline 276 Englewood Ave & Boston & Light & Pre-2000 & 24179 & 0.65 & 282 Hybrid \\
\hline 277 Fairbanks St & Boston & Light & Pre-2000 & 25477 & 0.53 & 189 Hybrid \\
\hline 278 Fenway Station & Boston & Light & Pre-2000 & 55097 & 0.91 & 203 Hybrid \\
\hline 279 Griggs St & Boston & Light & Pre-2000 & 48881 & 0.80 & 330 Hybrid \\
\hline 280 Harvard Ave & Boston & Light & Pre-2000 & 44685 & 0.71 & 351 Hybrid \\
\hline 281 Hawes St & Boston & Light & Pre-2000 & 30492 & 0.75 & 250 Hybrid \\
\hline 282 Heath St Platform & Boston & Light & Pre-2000 & 34350 & 0.77 & 256 Hybrid \\
\hline 283 Kenmore Station & Boston & Light & Pre-2000 & 58572 & 0.88 & 238 Hybrid \\
\hline 284 Kent St & Boston & Light & Pre-2000 & 31773 & 0.72 & 240 Hybrid \\
\hline 285 Lechmere & Boston & Light & Pre-2000 & 43217 & 0.97 & 245 Hybrid \\
\hline 286 Longwood Med Area & Boston & Light & Pre-2000 & 92247 & 0.60 & 301 Hybrid \\
\hline 287 Longwood Station & Boston & Light & Pre-2000 & 60625 & 0.76 & 215 Hybrid \\
\hline 288 Mattapan Station & Boston & Light & Pre-2000 & 13204 & 0.80 & 263 Hybrid \\
\hline 289 Milton Station & Boston & Light & Pre-2000 & 7902 & 0.74 & 160 Hybrid \\
\hline 290 Museum of Fine Arts & Boston & Light & Pre-2000 & 76287 & 0.32 & 263 Hybrid \\
\hline 291 Newton Highlands Station & Boston & Light & Pre-2000 & 7553 & 0.42 & 249 Hybrid \\
\hline 292 Northeastern & Boston & Light & Pre-2000 & 74363 & 0.56 & 259 Hybrid \\
\hline 293 Packards Corner & Boston & Light & Pre-2000 & 49880 & 0.85 & 299 Hybrid \\
\hline 294 Pleasant St & Boston & Light & Pre-2000 & 46934 & 0.91 & 273 Hybrid \\
\hline 295 Reservoir Station & Boston & Light & Pre-2000 & 18019 & 0.68 & 211 Hybrid \\
\hline 296 Riverway & Boston & Light & Pre-2000 & 48399 & 0.82 & 297 Hybrid \\
\hline 297 Saint Mary St & Boston & Light & Pre-2000 & 41125 & 0.92 & 232 Hybrid \\
\hline 298 Saint Paul St/Beacon & Boston & Light & Pre-2000 & 33430 & 0.72 & 244 Hybrid \\
\hline 299 Saint Paul St/Commonwealth & Boston & Light & Pre-2000 & 41695 & 0.93 & 232 Hybrid \\
\hline 300 Science Park & Boston & Light & Pre-2000 & 81457 & 0.75 & 235 Hybrid \\
\hline 301 South St & Boston & Light & Pre-2000 & 23519 & 0.70 & 208 Hybrid \\
\hline 302 Summit Ave & Boston & Light & Pre-2000 & 36972 & 0.63 & 232 Hybrid \\
\hline
\end{tabular}




\begin{tabular}{|c|c|c|c|c|c|c|}
\hline 303 Sutherland Rd & Boston & Light & Pre-2000 & 36762 & 0.56 & 307 Hybrid \\
\hline 304 Tappan St & Boston & Light & Pre-2000 & 22272 & 0.45 & 224 Hybrid \\
\hline 305 Waban Station & Boston & Light & Pre-2000 & 4649 & 0.56 & 155 Hybrid \\
\hline 306 Warren St & Boston & Light & Pre-2000 & 39932 & 0.83 & 311 Hybrid \\
\hline 307 Washington Sq & Boston & Light & Pre-2000 & 25229 & 0.48 & 210 Hybrid \\
\hline 308 Washington St & Boston & Light & Pre-2000 & 36362 & 0.68 & 273 Hybrid \\
\hline 309 Woodland Station & Boston & Light & Pre-2000 & 8986 & 0.70 & 66 Hybrid \\
\hline 310 10th and Osage Station & Denver & Light & Pre-2000 & 12220 & 0.75 & 125 Hybrid \\
\hline 311 25th And Welton Station & Denver & Light & Pre-2000 & 13158 & 0.62 & 211 Hybrid \\
\hline 312 27th and Welton Station & Denver & Light & Pre-2000 & 13431 & 0.50 & 209 Hybrid \\
\hline 313 29th and Welton Station & Denver & Light & Pre-2000 & 13188 & 0.41 & 225 Hybrid \\
\hline 314 30th and Downing Station & Denver & Light & Pre-2000 & 12629 & 0.44 & 221 Hybrid \\
\hline 315 Alameda Station & Denver & Light & Pre-2000 & 13119 & 0.89 & 115 Hybrid \\
\hline 316 Auraria West Station & Denver & Light & 2002 & 6870 & 0.98 & 123 Hybrid \\
\hline 317 Colfax at Auraria Station & Denver & Light & Pre-2000 & 17784 & 0.87 & 188 Hybrid \\
\hline 318 Colorado Station & Denver & Light & 2006 & 16669 & 0.80 & 121 Hybrid \\
\hline 319 Dry Creek Station & Denver & Light & 2006 & 11596 & 0.77 & 165 Hybrid \\
\hline 320 Englewood Station & Denver & Light & Pre-2000 & 11859 & 1.00 & 146 Hybrid \\
\hline 321 Evans Station & Denver & Light & Pre-2000 & 7444 & 0.82 & 139 Hybrid \\
\hline 322 Hwy I-25 and Broadway Stn & Denver & Light & Pre-2000 & 7446 & 0.72 & 53 Hybrid \\
\hline $\begin{array}{l}323 \text { Invesco Field at Mile High } \\
\text { Station }\end{array}$ & Denver & Light & 2002 & 4852 & 0.82 & 113 Hybrid \\
\hline 324 Littleton / Downtown Station & Denver & Light & Pre-2000 & 12414 & 0.78 & 151 Hybrid \\
\hline $\begin{array}{l}325 \text { Oxford-City of Sheridan } \\
\text { Station }\end{array}$ & Denver & Light & Pre-2000 & 6104 & 0.86 & 77 Hybrid \\
\hline 326 Pepsi Center/Elitch’s Stn & Denver & Light & 2002 & 15479 & 0.56 & 166 Hybrid \\
\hline $\begin{array}{l}327 \text { Theatre District/Convention Ctr } \\
\text { Stn }\end{array}$ & Denver & Light & Pre-2000 & 84391 & 0.48 & 236 Hybrid \\
\hline 328 Union Station Lrt & Denver & Light & 2002 & 72046 & 0.69 & 210 Hybrid \\
\hline 329 Golden Glades & Miami & Commuter & Pre-2000 & 5516 & 0.77 & 33 Hybrid \\
\hline 330 Hialeah Market & Miami & Commuter & Pre-2000 & 9487 & 0.57 & 159 Hybrid \\
\hline 331 Metrorail Transfer & Miami & Commuter & Pre-2000 & 5806 & 0.78 & 168 Hybrid \\
\hline 332 Opa-Locka & Miami & Commuter & Pre-2000 & 7991 & 0.74 & 209 Hybrid \\
\hline 333 Allapattah Station Rail & Miami & Heavy & Pre-2000 & 14066 & 0.63 & 249 Hybrid \\
\hline 334 Brickell Station Rail & Miami & Heavy & Pre-2000 & 52522 & 0.85 & 216 Hybrid \\
\hline 335 Brownsville Station Rail & Miami & Heavy & Pre-2000 & 9981 & 0.78 & 260 Hybrid \\
\hline 336 Civic Cntr. Station Rail & Miami & Heavy & Pre-2000 & 46447 & 0.59 & 172 Hybrid \\
\hline 337 Coconut Grove Station & Miami & Heavy & Pre-2000 & 15310 & 0.61 & 321 Hybrid \\
\hline 338 Culmer Station Rail & Miami & Heavy & Pre-2000 & 13200 & 0.89 & 169 Hybrid \\
\hline 339 Dadeland North Station Rail & Miami & Heavy & Pre-2000 & 13672 & 0.78 & 168 Hybrid \\
\hline 340 Dadeland South Station Rail & Miami & Heavy & Pre-2000 & 25731 & 0.70 & 140 Hybrid \\
\hline 341 Douglas Road Station Rail & Miami & Heavy & Pre-2000 & 18505 & 0.90 & 251 Hybrid \\
\hline 342 Earlington Hts. Stat. Rail & Miami & Heavy & Pre-2000 & 11004 & 0.78 & 198 Hybrid \\
\hline
\end{tabular}




\begin{tabular}{|c|c|c|c|c|c|c|}
\hline 343 Government Ctr. Stat. Rail & Miami & Heavy & Pre-2000 & 51747 & 0.75 & 187 Hybrid \\
\hline 344 Hialeah Station Rail & Miami & Heavy & Pre-2000 & 14676 & 0.74 & 195 Hybrid \\
\hline 345 M.L. King Station Rail & Miami & Heavy & Pre-2000 & 9093 & 0.88 & 255 Hybrid \\
\hline 346 Northside Station Rail & Miami & Heavy & Pre-2000 & 7097 & 0.86 & 188 Hybrid \\
\hline 347 Okeechobee Station Rail & Miami & Heavy & Pre-2000 & 10104 & 0.88 & 145 Hybrid \\
\hline 348 Overtown/Arena Stat. Rail & Miami & Heavy & Pre-2000 & 33123 & 0.91 & 188 Hybrid \\
\hline 349 Santa Clara Station Rail & Miami & Heavy & Pre-2000 & 27716 & 0.93 & 182 Hybrid \\
\hline 350 South Miami Station Rail & Miami & Heavy & Pre-2000 & 22176 & 0.92 & 260 Hybrid \\
\hline 351 Tri-Rail Station Rail & Miami & Heavy & Pre-2000 & 7957 & 0.73 & 172 Hybrid \\
\hline 352 University Station Rail & Miami & Heavy & Pre-2000 & 10583 & 0.92 & 222 Hybrid \\
\hline 353 Vizcaya Station Rail & Miami & Heavy & Pre-2000 & 9455 & 0.71 & 231 Hybrid \\
\hline 354 Arena/State Plaza Station & Miami & Light & Pre-2000 & 43698 & 0.78 & 194 Hybrid \\
\hline 355 Bayfront Park Station & Miami & Light & Pre-2000 & 76220 & 0.63 & 182 Hybrid \\
\hline 356 Bicentennial Park Station & Miami & Light & Pre-2000 & 17749 & 0.69 & 187 Hybrid \\
\hline 357 Brickell Metromover Station & Miami & Light & Pre-2000 & 51204 & 0.87 & 232 Hybrid \\
\hline 358 College North Station & Miami & Light & Pre-2000 & 47438 & 0.71 & 180 Hybrid \\
\hline 359 College/Bayside Station & Miami & Light & Pre-2000 & 56666 & 0.64 & 193 Hybrid \\
\hline 360 Eighth Street Station & Miami & Light & Pre-2000 & 67315 & 0.67 & 181 Hybrid \\
\hline 361 Eleventh Street Station & Miami & Light & Pre-2000 & 16889 & 0.83 & 229 Hybrid \\
\hline 362 Fifth Street Station & Miami & Light & Pre-2000 & 67212 & 0.55 & 165 Hybrid \\
\hline 363 Financial District Station & Miami & Light & Pre-2000 & 60024 & 0.89 & 179 Hybrid \\
\hline 364 First Street Station & Miami & Light & Pre-2000 & 69395 & 0.65 & 192 Hybrid \\
\hline 365 Government Center Station & Miami & Light & Pre-2000 & 50824 & 0.76 & 185 Hybrid \\
\hline 366 Knight Center Station & Miami & Light & Pre-2000 & 76995 & 0.55 & 196 Hybrid \\
\hline 367 NE 2 Ave @NE 2 St & Miami & Light & Pre-2000 & 69395 & 0.65 & 192 Hybrid \\
\hline 368 NE 2 Ave @NE 4 St & Miami & Light & Pre-2000 & 56666 & 0.64 & 193 Hybrid \\
\hline 369 NE 2 Ave @NE 7 St & Miami & Light & Pre-2000 & 28767 & 0.73 & 173 Hybrid \\
\hline 370 NE 2 Ave @NE 8 St & Miami & Light & Pre-2000 & 20880 & 0.76 & 174 Hybrid \\
\hline 371 NW 1 Ave @NW 5 St & Miami & Light & Pre-2000 & 43698 & 0.78 & 194 Hybrid \\
\hline 372 Omni Metromover Station & Miami & Light & Pre-2000 & 25028 & 0.79 & 231 Hybrid \\
\hline 373 Riverwalk Station & Miami & Light & Pre-2000 & 72265 & 0.55 & 183 Hybrid \\
\hline 374 School Board Station & Miami & Light & Pre-2000 & 15052 & 0.88 & 260 Hybrid \\
\hline 375 SE 4 St @S Miami Ave & Miami & Light & Pre-2000 & 67470 & 0.61 & 179 Hybrid \\
\hline 376 SW 1 St @S Miami Ave & Miami & Light & Pre-2000 & 69395 & 0.65 & 192 Hybrid \\
\hline 377 Tenth Street Promenade Station & Miami & Light & Pre-2000 & 65303 & 0.81 & 198 Hybrid \\
\hline 378 Anoka Station & Minneapolis & Commuter & 2009 & 4171 & 0.66 & 133 Hybrid \\
\hline 37946 St Station & Minneapolis & Light & 2004 & 7014 & 0.54 & 142 Hybrid \\
\hline 380 Lake St Midtown Sta & Minneapolis & Light & 2004 & 9613 & 0.63 & 113 Hybrid \\
\hline 381 Beaverton TC Wes Station & Portland & Commuter & Pre-2000 & 10471 & 0.79 & 218 Hybrid \\
\hline $382 \mathrm{Pdx}$ & Portland & Commuter & Pre-2000 & 48591 & 0.62 & 363 Hybrid \\
\hline 383 Tigard TC Wes Station & Portland & Commuter & 2009 & 9010 & 0.96 & 133 Hybrid \\
\hline 384 Tualatin Wes Station & Portland & Commuter & 2009 & 8455 & 0.92 & 111 Hybrid \\
\hline
\end{tabular}




\begin{tabular}{|c|c|c|c|c|c|c|}
\hline 385 Beaverton Central Max Station & Portland & Light & Pre-2000 & 10194 & 0.71 & 201 Hybrid \\
\hline 386 Beaverton Creek Max Station & Portland & Light & Pre-2000 & 11602 & 0.91 & 32 Hybrid \\
\hline 387 Beaverton TC Max Station & Portland & Light & Pre-2000 & 10437 & 0.80 & 205 Hybrid \\
\hline 388 Civic Drive Max Station & Portland & Light & Pre-2000 & 11660 & 0.84 & 140 Hybrid \\
\hline 389 Cleveland Ave Max Station & Portland & Light & Pre-2000 & 7916 & 0.74 & 159 Hybrid \\
\hline 390 E 102nd Ave Max Station & Portland & Light & Pre-2000 & 14198 & 0.78 & 206 Hybrid \\
\hline 391 E 122nd Ave Max Station & Portland & Light & Pre-2000 & 8211 & 0.87 & 148 Hybrid \\
\hline 392 E 172nd Ave Max Station & Portland & Light & Pre-2000 & 8779 & 0.58 & 140 Hybrid \\
\hline 393 E 181st Ave Max Station & Portland & Light & Pre-2000 & 9344 & 0.75 & 138 Hybrid \\
\hline $\begin{array}{l}394 \text { Elmonica/SW 170th Ave Max } \\
\text { Station }\end{array}$ & Portland & Light & Pre-2000 & 9155 & 0.80 & 136 Hybrid \\
\hline $\begin{array}{l}395 \text { Gateway/NE 99th Ave Tc Max } \\
\text { Station }\end{array}$ & Portland & Light & Pre-2000 & 9511 & 0.89 & 176 Hybrid \\
\hline $\begin{array}{l}396 \text { Goose Hollow/SW Jefferson St } \\
\text { Max Station }\end{array}$ & Portland & Light & Pre-2000 & 27906 & 0.94 & 306 Hybrid \\
\hline $\begin{array}{l}397 \text { Gresham Central TC Max } \\
\text { Station }\end{array}$ & Portland & Light & Pre-2000 & 8855 & 0.84 & 195 Hybrid \\
\hline 398 Gresham City Hall Max Station & Portland & Light & Pre-2000 & 9632 & 0.86 & 163 Hybrid \\
\hline $\begin{array}{l}399 \text { Hatfield Government Center } \\
\text { Max Station }\end{array}$ & Portland & Light & Pre-2000 & 12063 & 0.97 & 168 Hybrid \\
\hline 400 Hawthorn Farm Max Station & Portland & Light & Pre-2000 & 9366 & 0.76 & 53 Hybrid \\
\hline $\begin{array}{l}401 \text { Hillsboro Central/SE 3rd Tc } \\
\text { Max Station }\end{array}$ & Portland & Light & Pre-2000 & 11134 & 0.99 & 175 Hybrid \\
\hline $\begin{array}{l}402 \text { Hollywood/NE 42nd Ave Tc } \\
\text { Max Station }\end{array}$ & Portland & Light & Pre-2000 & 15740 & 0.78 & 269 Hybrid \\
\hline $\begin{array}{l}403 \text { Kenton/N Denver Ave Max } \\
\text { Station }\end{array}$ & Portland & Light & 2004 & 6396 & 0.66 & 241 Hybrid \\
\hline $\begin{array}{l}404 \text { Kings Hill/SW Salmon St Max } \\
\text { Station }\end{array}$ & Portland & Light & Pre-2000 & 38267 & 1.00 & 375 Hybrid \\
\hline $\begin{array}{l}405 \text { Lents/SE Foster Rd Max } \\
\text { Station }\end{array}$ & Portland & Light & 2009 & 6290 & 0.58 & 234 Hybrid \\
\hline $\begin{array}{l}406 \text { Lloyd Center/NE 11th Ave } \\
\text { Max Station }\end{array}$ & Portland & Light & Pre-2000 & 35614 & 0.43 & 216 Hybrid \\
\hline $\begin{array}{l}407 \text { Marquam Hill Upper Tram } \\
\text { Terminal }\end{array}$ & Portland & Light & 2006 & 33561 & 0.74 & 47 Hybrid \\
\hline $\begin{array}{l}408 \text { Merlo Rd/SW 158th Ave Max } \\
\text { Station }\end{array}$ & Portland & Light & Pre-2000 & 9838 & 0.73 & 52 Hybrid \\
\hline 409 Millikan Way Max Station & Portland & Light & Pre-2000 & 10479 & 0.68 & 75 Hybrid \\
\hline 410 N Killingsworth St Max Station & Portland & Light & 2004 & 9543 & 0.55 & 311 Hybrid \\
\hline 411 N Lombard TC Max Station & Portland & Light & 2004 & 8803 & 0.52 & 241 Hybrid \\
\hline 412 N Prescott St Max Station & Portland & Light & 2004 & 9076 & 0.54 & 285 Hybrid \\
\hline 413 NE 60th Ave Max Station & Portland & Light & Pre-2000 & 11920 & 0.52 & 257 Hybrid \\
\hline 414 NE 82nd Ave Max Station & Portland & Light & Pre-2000 & 7363 & 0.53 & 218 Hybrid \\
\hline $\begin{array}{l}415 \text { Orenco/NW 231St Ave Max } \\
\text { Station }\end{array}$ & Portland & Light & Pre-2000 & 8038 & 0.67 & 198 Hybrid \\
\hline 416 Overlook Park Max Station & Portland & Light & 2004 & 10154 & 0.80 & 233 Hybrid \\
\hline
\end{tabular}




\begin{tabular}{|c|c|c|c|c|c|c|}
\hline $\begin{array}{l}417 \text { Parkrose/Sumner TC Max } \\
\text { Station }\end{array}$ & Portland & Light & 2001 & 6247 & 0.60 & 160 Hybrid \\
\hline 418 PGE Park Max Station & Portland & Light & Pre-2000 & 46725 & 0.99 & 401 Hybrid \\
\hline $\begin{array}{l}419 \text { Quatama/NW 205th Ave Max } \\
\text { Station }\end{array}$ & Portland & Light & Pre-2000 & 6858 & 0.56 & 185 Hybrid \\
\hline $\begin{array}{l}420 \text { Rockwood/E 188th Ave Max } \\
\text { Station }\end{array}$ & Portland & Light & Pre-2000 & 9047 & 0.66 & 138 Hybrid \\
\hline 421 Rosa Parks Max Station & Portland & Light & 2004 & 8979 & 0.34 & 255 Hybrid \\
\hline $\begin{array}{l}422 \text { Ruby Junction/E 197th Ave } \\
\text { Max Station }\end{array}$ & Portland & Light & Pre-2000 & 7317 & 0.73 & 70 Hybrid \\
\hline 423 SE Division St Max Station & Portland & Light & 2009 & 6253 & 0.66 & 125 Hybrid \\
\hline 424 SE Main St Max Station & Portland & Light & 2009 & 12018 & 0.97 & 102 Hybrid \\
\hline 425 SE Powell Blvd Max Station & Portland & Light & 2009 & 5706 & 0.99 & 80 Hybrid \\
\hline $\begin{array}{l}426 \text { South Waterfront Lower Tram } \\
\text { Terminal }\end{array}$ & Portland & Light & 2006 & 15842 & 0.86 & 241 Hybrid \\
\hline $\begin{array}{l}427 \text { Tuality Hospital/SE 8th Ave } \\
\text { Max Station }\end{array}$ & Portland & Light & Pre-2000 & 9942 & 0.95 & 173 Hybrid \\
\hline $\begin{array}{l}428 \text { Union Station/NW 5th and } \\
\text { Glisan St Max Stn }\end{array}$ & Portland & Light & 2009 & 62076 & 0.56 & 380 Hybrid \\
\hline $\begin{array}{l}429 \text { Union Station/NW 6th and } \\
\text { Hoyt St Max Stn }\end{array}$ & Portland & Light & 2009 & 56546 & 0.60 & 374 Hybrid \\
\hline $\begin{array}{l}430 \text { Washington/SE 12th Ave Max } \\
\text { Station }\end{array}$ & Portland & Light & Pre-2000 & 8850 & 0.73 & 156 Hybrid \\
\hline $\begin{array}{l}431 \text { Willow Creek/SW 185th Ave } \\
\text { TC Max Station }\end{array}$ & Portland & Light & Pre-2000 & 7563 & 0.78 & 111 Hybrid \\
\hline 432 Salt Lake Central Station & \multicolumn{2}{|c|}{ SaltLakeCity Commuter } & 2008 & 11193 & 0.67 & 102 Hybrid \\
\hline 433900 East Station & \multicolumn{2}{|c|}{ SaltLakeCity Light } & 2005 & 19412 & 0.72 & 224 Hybrid \\
\hline 434900 South & \multicolumn{2}{|c|}{ SaltLakeCity Light } & 2005 & 11441 & 0.90 & 196 Hybrid \\
\hline 435 Arena & \multicolumn{2}{|c|}{ SaltLakeCity Light } & Pre-2000 & 34913 & 0.85 & 127 Hybrid \\
\hline 436 Ball Park Station & \multicolumn{2}{|c|}{ SaltLakeCity Light } & Pre-2000 & 9803 & 0.75 & 150 Hybrid \\
\hline 437 Bingham Junction & \multicolumn{2}{|c|}{ SaltLakeCity Light } & 2011 & 2208 & 0.84 & 0 Hybrid \\
\hline 438 City Center Station & \multicolumn{2}{|c|}{ SaltLakeCity Light } & Pre-2000 & 79778 & 0.85 & 158 Hybrid \\
\hline 439 Courthouse Station & \multicolumn{2}{|c|}{ SaltLakeCity Light } & Pre-2000 & 44089 & 0.70 & 160 Hybrid \\
\hline 440 Decker Lake & \multicolumn{2}{|c|}{ SaltLakeCity Light } & 2011 & 12034 & 0.98 & 103 Hybrid \\
\hline 441 Fashion Place West & \multicolumn{2}{|c|}{ SaltLakeCity Light } & Pre-2000 & 6432 & 0.78 & 103 Hybrid \\
\hline 442 Gallivan Plaza & \multicolumn{2}{|c|}{ SaltLakeCity Light } & Pre-2000 & 69939 & 0.82 & 153 Hybrid \\
\hline 443 Historic Gardner & \multicolumn{2}{|c|}{ SaltLakeCity Light } & 2011 & 5210 & 0.99 & 67 Hybrid \\
\hline 444 Historic Sandy & \multicolumn{2}{|c|}{ SaltLakeCity Light } & Pre-2000 & 7825 & 0.79 & 316 Hybrid \\
\hline 445 Jordan Valley & \multicolumn{2}{|c|}{ SaltLakeCity Light } & 2011 & 7158 & 0.77 & 140 Hybrid \\
\hline 446 Library Station & \multicolumn{2}{|c|}{ SaltLakeCity Light } & 2001 & 51383 & 0.88 & 154 Hybrid \\
\hline 447 Meadowbrook Station & \multicolumn{2}{|c|}{ SaltLakeCity Light } & Pre-2000 & 8402 & 0.96 & 78 Hybrid \\
\hline 448 Midvale Center Station & \multicolumn{2}{|c|}{ SaltLakeCity Light } & Pre-2000 & 5888 & 0.80 & 124 Hybrid \\
\hline 449 Midvale Fort Union & \multicolumn{2}{|c|}{ SaltLakeCity Light } & Pre-2000 & 5782 & 0.60 & 171 Hybrid \\
\hline 450 Millcreek Station & \multicolumn{2}{|c|}{ SaltLakeCity Light } & Pre-2000 & 9570 & 0.95 & 87 Hybrid \\
\hline 451 Murray Central Station & \multicolumn{2}{|c|}{ SaltLakeCity Light } & Pre-2000 & 22484 & 0.96 & 118 Hybrid \\
\hline
\end{tabular}




\begin{tabular}{|c|c|c|c|c|c|c|}
\hline 452 Old Greektown & \multicolumn{2}{|c|}{ SaltLakeCity Light } & 2008 & 26032 & 0.88 & 107 Hybrid \\
\hline 453 Planetarium & \multicolumn{2}{|c|}{ SaltLakeCity Light } & 2008 & 31259 & 0.86 & 127 Hybrid \\
\hline 454 Redwood Junction & \multicolumn{2}{|c|}{ SaltLakeCity Light } & 2011 & 8011 & 0.92 & 108 Hybrid \\
\hline 455 River Trail & \multicolumn{2}{|c|}{ SaltLakeCity Light } & 2011 & 10847 & 0.97 & 78 Hybrid \\
\hline 456 Sandy Civic Center & \multicolumn{2}{|c|}{ SaltLakeCity Light } & Pre-2000 & 6289 & 0.60 & 148 Hybrid \\
\hline 457 Sandy Expo & \multicolumn{2}{|c|}{ SaltLakeCity Light } & 2006 & 11953 & 0.98 & 112 Hybrid \\
\hline 458 Stadium & \multicolumn{2}{|c|}{ SaltLakeCity Light } & 2001 & 17826 & 0.71 & 107 Hybrid \\
\hline 459 Temple Square Station & \multicolumn{2}{|c|}{ SaltLakeCity Light } & Pre-2000 & 55670 & 0.86 & 133 Hybrid \\
\hline 460 Trolley Square Station & \multicolumn{2}{|c|}{ SaltLakeCity Light } & 2001 & 24387 & 0.80 & 195 Hybrid \\
\hline 461 West Jordan City Center & \multicolumn{2}{|c|}{ SaltLakeCity Light } & 2011 & 6934 & 0.54 & 176 Hybrid \\
\hline 462 West Valley Central Station & \multicolumn{2}{|c|}{ SaltLakeCity Light } & 2011 & 11866 & 0.86 & 154 Hybrid \\
\hline 463 Auburn Station & Seattle & Commuter & Pre-2000 & 5103 & 0.85 & 176 Hybrid \\
\hline 464 Edmonds Station & Seattle & Commuter & 2003 & 2689 & 0.71 & 104 Hybrid \\
\hline 465 Everett Station & Seattle & Commuter & 2003 & 12479 & 0.76 & 139 Hybrid \\
\hline 466 Kent Station & Seattle & Commuter & 2001 & 5888 & 0.97 & 172 Hybrid \\
\hline 467 King Street Station & Seattle & Commuter & Pre-2000 & 69723 & 0.87 & 319 Hybrid \\
\hline 468 Mukilteo Station & Seattle & Commuter & 2003 & 684 & 0.68 & 141 Hybrid \\
\hline 469 Puyallup Station & Seattle & Commuter & 2001 & 6993 & 0.89 & 230 Hybrid \\
\hline 470 Sumner Station & Seattle & Commuter & Pre-2000 & 4676 & 0.75 & 184 Hybrid \\
\hline 471 Tacoma & Seattle & Commuter & Pre-2000 & 4356 & 0.67 & 138 Hybrid \\
\hline 472 Tacoma Dome Station & Seattle & Commuter & $\begin{array}{r}\text { Pre- } \\
2000 / 200\end{array}$ & 4300 & 0.64 & 127 Hybrid \\
\hline 473 Columbia City & Seattle & Light & $\begin{array}{r}3 \\
2009\end{array}$ & 10869 & 0.67 & 247 Hybrid \\
\hline 474 Commerce Street Station & Seattle & Light & 2003 & 36046 & 0.76 & 232 Hybrid \\
\hline 475 Convention Center Station & Seattle & Light & 2003 & 32222 & 0.91 & 242 Hybrid \\
\hline 476 Fairview Ave N and Aloha St & Seattle & Light & 2007 & 26920 & 0.74 & 174 Hybrid \\
\hline 477 Mount Baker & Seattle & Light & 2009 & 10356 & 0.85 & 239 Hybrid \\
\hline 478 Othello & Seattle & Light & 2009 & 10728 & 0.66 & 167 Hybrid \\
\hline 479 Rainier Beach & Seattle & Light & 2009 & 6085 & 0.57 & 170 Hybrid \\
\hline 480 SLU Streetcar and Terry Ave N & Seattle & Light & 2007 & 31522 & 0.75 & 238 Hybrid \\
\hline 481 South 25th Street Station & Seattle & Light & 2003 & 5688 & 0.93 & 181 Hybrid \\
\hline 482 Stadium & Seattle & Light & 2009 & 18796 & 0.66 & 157 Hybrid \\
\hline 483 Terry Ave N and Republican St & Seattle & Light & 2007 & 36786 & 0.83 & 260 Hybrid \\
\hline 484 Terry Ave N and Thomas St & Seattle & Light & 2007 & 49702 & 0.83 & 274 Hybrid \\
\hline 485 Theater District Station & Seattle & Light & 2003 & 36578 & 0.81 & 212 Hybrid \\
\hline 486 Tukwila International Blvd & Seattle & Light & 2009 & 5500 & 0.73 & 104 Hybrid \\
\hline 487 Union Station & Seattle & Light & 2003 & 14885 & 0.88 & 230 Hybrid \\
\hline $\begin{array}{l}488 \text { Westlake Ave } \mathrm{N} \text { and Harrison } \\
\text { St }\end{array}$ & Seattle & Light & 2007 & 53745 & 0.81 & 289 Hybrid \\
\hline 489 Westlake Ave N and Mercer St & Seattle & Light & 2007 & 33921 & 0.80 & 256 Hybrid \\
\hline 490 Five Points Station & Atlanta & Heavy & Pre-2000 & 117818 & 0.50 & 260 TOD \\
\hline
\end{tabular}




\begin{tabular}{|c|c|c|c|c|c|c|}
\hline 491 Peachtree Center Station & Atlanta & Heavy & Pre-2000 & 117224 & 0.31 & 245 TOD \\
\hline 492 Back Bay & Boston & Commuter & Pre-2000 & 139580 & 0.99 & 310 TOD \\
\hline 493 Aquarium Station & Boston & Heavy & Pre-2000 & 209757 & 0.96 & 536 TOD \\
\hline 494 Back Bay Station & Boston & Heavy & Pre-2000 & 139941 & 0.99 & 308 TOD \\
\hline 495 Bowdoin Station Blue Line & Boston & Heavy & Pre-2000 & 206501 & 0.95 & 576 TOD \\
\hline 496 Charles/Mgh Station & Boston & Heavy & Pre-2000 & 82861 & 0.74 & 436 TOD \\
\hline 497 Chinatown Station & Boston & Heavy & Pre-2000 & 187134 & 0.94 & 455 TOD \\
\hline 498 Downtown Crossing & Boston & Heavy & Pre-2000 & 283934 & 0.93 & 504 TOD \\
\hline 499 Government Ctr Station & Boston & Heavy & Pre-2000 & 244676 & 0.94 & 540 TOD \\
\hline 500 Haymarket & Boston & Heavy & Pre-2000 & 189203 & 0.97 & 634 TOD \\
\hline 501 Massachusetts Ave Station & Boston & Heavy & Pre-2000 & 80296 & 0.87 & 360 TOD \\
\hline 502 North Station & Boston & Heavy & Pre-2000 & 94767 & 0.91 & 527 TOD \\
\hline 503 Park St Station & Boston & Heavy & Pre-2000 & 274644 & 0.97 & 507 TOD \\
\hline 504 South Station & Boston & Heavy & Pre-2000 & 216171 & 0.95 & 409 TOD \\
\hline 505 State St Station & Boston & Heavy & Pre-2000 & 250530 & 0.91 & 544 TOD \\
\hline 506 Tufts Medical Ctr & Boston & Heavy & Pre-2000 & 129180 & 0.93 & 423 TOD \\
\hline 507 Arlington Station & Boston & Light & Pre-2000 & 135560 & 0.96 & 338 TOD \\
\hline 508 Boylston Station & Boston & Light & Pre-2000 & 187240 & 0.94 & 459 TOD \\
\hline 509 Brigham Circle & Boston & Light & Pre-2000 & 105570 & 0.74 & 330 TOD \\
\hline 510 Copley Station & Boston & Light & Pre-2000 & 151055 & 0.99 & 243 TOD \\
\hline 511 Fenwood Rd & Boston & Light & Pre-2000 & 103590 & 0.78 & 344 TOD \\
\hline 512 Government Center Station & Boston & Light & Pre-2000 & 244676 & 0.94 & 540 TOD \\
\hline 513 Hynes Station & Boston & Light & Pre-2000 & 81687 & 0.97 & 252 TOD \\
\hline 514 Mission Park & Boston & Light & Pre-2000 & 80551 & 0.88 & 326 TOD \\
\hline 515 Prudential Station & Boston & Light & Pre-2000 & 108649 & 0.99 & 302 TOD \\
\hline 516 Symphony Station & Boston & Light & Pre-2000 & 86228 & 0.89 & 348 TOD \\
\hline 517 16th and California Station & Denver & Light & Pre-2000 & 139179 & 0.39 & 241 TOD \\
\hline 518 16th and Stout Station & Denver & Light & Pre-2000 & 143196 & 0.45 & 220 TOD \\
\hline 519 18th and California Station & Denver & Light & Pre-2000 & 132834 & 0.59 & 228 TOD \\
\hline 520 18th and Stout Station & Denver & Light & Pre-2000 & 128021 & 0.68 & 227 TOD \\
\hline 521 20th and Welton Station & Denver & Light & Pre-2000 & 104711 & 0.83 & 220 TOD \\
\hline 522 Govt Plaza Station & Minneapolis & Light & 2004 & 155399 & 0.63 & 215 TOD \\
\hline 523 Nicollet Mall Station & Minneapolis & Light & 2004 & 174036 & 0.57 & 214 TOD \\
\hline 524 Warehouse Station & Minneapolis & Light & 2004 & 132309 & 0.61 & 200 TOD \\
\hline $\begin{array}{l}525 \text { City Hall/SW 5th and Jefferson } \\
\text { St Max Stn }\end{array}$ & Portland & Light & 2009 & 112145 & 0.71 & 393 TOD \\
\hline $\begin{array}{l}526 \text { Galleria/SW 10th Ave Max } \\
\text { Station }\end{array}$ & Portland & Light & Pre-2000 & 99968 & 0.83 & 459 TOD \\
\hline $\begin{array}{l}527 \text { Library/SW 9th Ave Max } \\
\text { Station }\end{array}$ & Portland & Light & Pre-2000 & 109588 & 0.80 & 448 TOD \\
\hline 528 Mall/SW 4th Ave Max Station & Portland & Light & Pre-2000 & 127230 & 0.43 & 460 TOD \\
\hline 529 Mall/SW 5th Ave Max Station & Portland & Light & Pre-2000 & 125151 & 0.48 & 475 TOD \\
\hline
\end{tabular}




\begin{tabular}{|c|c|c|c|c|c|c|}
\hline $\begin{array}{l}530 \text { Morrison/SW 3rd Ave Max } \\
\text { Station }\end{array}$ & Portland & Light & Pre-2000 & 128148 & 0.27 & 455 TOD \\
\hline $\begin{array}{l}531 \text { NW 5th and Couch St Max } \\
\text { Station }\end{array}$ & Portland & Light & 2009 & 84316 & 0.37 & 448 TOD \\
\hline $\begin{array}{l}532 \text { NW 6th and Davis St Max } \\
\text { Station }\end{array}$ & Portland & Light & 2009 & 80541 & 0.39 & 449 TOD \\
\hline 533 Oak/ SW 1st Ave Max Station & Portland & Light & Pre-2000 & 102246 & 0.20 & 465 TOD \\
\hline $\begin{array}{l}534 \text { Old Town/Chinatown Max } \\
\text { Station }\end{array}$ & Portland & Light & Pre-2000 & 68383 & 0.48 & 436 TOD \\
\hline $\begin{array}{l}535 \text { Pioneer Courthouse/Sw 6th } \\
\text { Ave Max Stn }\end{array}$ & Portland & Light & 2009 & 121964 & 0.57 & 459 TOD \\
\hline $\begin{array}{l}536 \text { Pioneer Place/SW 5th Ave Max } \\
\text { Station }\end{array}$ & Portland & Light & 2009 & 125023 & 0.50 & 447 TOD \\
\hline $\begin{array}{l}537 \text { Pioneer Square North Max } \\
\text { Station }\end{array}$ & Portland & Light & Pre-2000 & 116398 & 0.66 & 449 TOD \\
\hline $\begin{array}{l}538 \text { Pioneer Square South Max } \\
\text { Station }\end{array}$ & Portland & Light & Pre-2000 & 122472 & 0.61 & 467 TOD \\
\hline $\begin{array}{l}539 \text { PSU/SW 5th and Mill St Max } \\
\text { Station }\end{array}$ & Portland & Light & 2009 & 92574 & 0.71 & 349 TOD \\
\hline $\begin{array}{l}540 \text { PSU/SW 6th and Montgomery } \\
\text { St Max Station }\end{array}$ & Portland & Light & 2009 & 84898 & 0.73 & 334 TOD \\
\hline $\begin{array}{l}541 \text { Skidmore Fountain Max } \\
\text { Station }\end{array}$ & Portland & Light & Pre-2000 & 82096 & 0.37 & 448 TOD \\
\hline $\begin{array}{l}542 \text { SW 5th and Oak St Max } \\
\text { Station }\end{array}$ & Portland & Light & 2009 & 103676 & 0.35 & 458 TOD \\
\hline $\begin{array}{l}543 \text { SW 6th and Madison St Max } \\
\text { Station }\end{array}$ & Portland & Light & 2009 & 113591 & 0.69 & 395 TOD \\
\hline $\begin{array}{l}544 \text { SW 6th and Pine St Max } \\
\text { Station }\end{array}$ & Portland & Light & 2009 & 95881 & 0.40 & 481 TOD \\
\hline 545 Yamhill District Max Station & Portland & Light & Pre-2000 & 130935 & 0.16 & 429 TOD \\
\hline 546 Westlake Ave and 7th Ave & Seattle & Light & 2007 & 131159 & 0.71 & 278 TOD \\
\hline 547 Westlake Ave and 9th Ave & Seattle & Light & 2007 & 97654 & 0.77 & 289 TOD \\
\hline 548 Westlake Ave and Olive Way & Seattle & Light & 2007 & 164945 & 0.64 & 278 TOD \\
\hline 549 Westlake Ave and Virginia St & Seattle & Light & 2007 & 139911 & 0.70 & 282 TOD \\
\hline
\end{tabular}


Transportation Research and Education Center

Portland State University

1900 S.W. Fourth Ave., Suite 175

Portland, OR 97201 